\title{
Disclosure, Enforcement and the Valuation of Equity
}

\author{
Julian S. Abée ${ }^{1}$ Michael Meser ${ }^{2 *} \quad$ Stefan Veith $^{3} \quad$ Jochen Zimmermann ${ }^{4}$ \\ 1.Department of Accounting and Control, Max-von-Laue-Str. 1, 28359 Bremen, University of Bremen, Germany \\ 2.Faculty of Business Studies, Alte Rabenstr. 2, 20148 Hamburg, Hochschule Fresenius Hamburg, Germany \\ 3.School of International Business, Werderstr. 73, 28199 Bremen, Bremen City University of Applied Sciences , \\ Germany \\ 4.Department of Accounting and Control, Max-von-Laue-Str. 1, 28359 Bremen, University of Bremen, Germany \\ *E-mail of the corresponding author: michael.meser@hs-fresenius.de
}

\begin{abstract}
Empirical evidence shows that higher levels of disclosure and enforcement do not consistently translate into higher firm valuations. This observation implies a real-life setting in which a richer information environment can shift investors' risk premiums upwards or downwards. However economic literature does not convincingly explain why adverse effects can occur. To fill this gap in research, we provide a model beyond the standard principal-agent framework that can explain valuation effects from augmented disclosure and enforcement regulation. We also show that country differences in regulatory effectiveness do not align with the legal system, but instead with structural strengths or difficulties of an economy. In a six country setting, investigating Canada, France, Germany, Japan, the UK and the U.S., we systematically capture regulatory changes and document varying valuation effects from mandatory disclosure regulation. Our analysis shows that valuation effects are driven by the share of "bad news" firms, which is higher in economies with structural difficulties. Effects from higher levels of disclosure are thus neither generalizable across economies nor dependent on the legal system as previously hypothesized.
\end{abstract}

Keywords: Equity Valuation; Disclosure; Enforcement; Panel data analysis.

DOI: $10.7176 /$ RJFA/10-8-04

Publication date: April $30^{\text {th }} 2019$

\section{Introduction}

Almost every major country has witnessed increasing emphasis on the regulation of financial reporting. The arrival of transnational International Financial Reporting Standards (IFRS) or the advent of new national supervisory agencies represent only the most outstanding examples of ever increasing levels of disclosure and enforcement regulation (Christensen et al. 2013). Literature associates the introduction of more regulation typically with a higher information level and predicts a positive effect on liquidity, cost of equity and equity valuation (e.g.; (Lambert et al. 2007); (Strohmenger 2014); (Verrecchia 2001)).

Many empirical studies have assessed the relationship between changes in financial reporting regulation and equity valuation (see e.g. (Brüggemann et al. 2013); (Healy \& Palepu 2001); (Leuz \& Wysocki 2016) for an overview). There is substantial empirical evidence for positive capital market effects from event studies (e.g. (Eleswarapu et al. 2004); (Ernstberger et al. 2012); (Hope 2003)), especially for the introduction of the IFRS (e.g. (Brown et al. 2014); (Byard et al. 2011); (Christensen et al. 2013); (Daske et al. 2008); (Daske et al. 2013); (Frino et al. 2013); (Horton et al. 2013); long-term studies corroborate most findings (e.g. (Core et al. 2015); (Daouk et al. 2006); (Dhaliwal et al. 2014); (Fu et al. 2012); (Meser et al. 2015)). However, there is also scattered evidence for a negative association of new disclosure regulations and equity valuation. (Armstrong et al. 2010) find negative capital market effects for European code law countries adopting IFRS. At closer inspection, by using a dummy variable for the legal system their sample may have been dominated by individual countries (Ireland and the UK being the only two common law out of the $18 \mathrm{EU}$ countries), and it is very likely that their documented effect is at the country-level, and not at the level of the legal system. In addition, (Hassan et al. 2009) conclude in their longterm study for the Egyptian market that there is a positive relationship between voluntary disclosure and firm value, but a negative one for mandatory disclosure regulation. They denote their results as "puzzling" and try to explain it ad hoc by regulatory costs. Both studies show that an explanation for the varying country-specific valuation effects in the course of mandatory disclosure regulation remains an open issue.

We provide a model that can explain positive or negative effects from a change in accounting regulation without invoking regulatory costs. In conformity with the majority of literature on capital market effects of accounting regulation we do not think that costs due to a higher level of mandatory disclosure regulation play such a major role that they outweigh the benefits. Instead, we posit the existence of systematic reasons for negative valuation effects when many firms are required to disclose of previously withheld bad news. Country-specific valuation effects depend on the heterogeneity of firms' disclosures within a country, controlled on the enforcement environment. Our model allows predicting capital market effects for specific countries based on the proportion of good news and bad news firms. A high proportion of bad news firms is likely to exist in countries with microeconomic or macroeconomic structural problems. 
We investigate a long time horizon between 1991 and 2010 with all relevant mandatory changes for disclosure and enforcement regulation for a cross-country sample. We use the leximetric model of (Meser et al. 2015) and extend it to six capital markets. Besides the United States of America (U.S.), these are Canada, France, Germany, Japan and the United Kingdom (UK). According to Worldbank data, the sample covers on average $71 \%$ of the global market capitalization over the sample period and represents different financial and legal systems. We provide empirical evidence for varying country-specific regulatory effects and point out the problems with the previously offered distinction in legal systems as the main explanation for these regulatory effects.

We proceed as follows. Section 2 provides conceptual underpinnings and our theoretical framework to describe the relation between disclosure, enforcement regulation and equity valuation. Section 3 introduces the leximetric measurement method and presents the measurement results for the six country cases. An empirical analysis of the relation between securities regulation and equity valuation follows in section 4 . Section 5 summarizes our main findings and gives some implications for researchers and regulators.

\section{Conceptual Underpinnings}

\subsection{Capital Market Regulation as a Response to Risks}

In the economics of imperfect information, (investor) risk arises from a lack of necessary information. Information can be incomplete, imprecise or uncertain (Aliev \& Huseynov 2014). Incomplete information is totally or partially not available. Sufficient information is imprecise if it has a low information content. Uncertain information refers to a lack of truthfulness.

Incomplete information makes it difficult to valuate an investment. Not only is it difficult for investors to distinguish between good and bad quality in the business world ex ante (Akerlof 1970). Likewise, future dynamics and the development of a business model are not predictable. In the literature, this risk about the quality of the business model is often referred to as the estimation risk (e.g. (Barry \& Brown 1985); (Klein \& Bawa 1976)). In addition, from the perspective of investors there is also an uncertainty relating to the quality of financial reporting, in particular its information content and truthfulness. Both quality concerns constitute the reporting risk, which comprises not only intentional opportunistic behavior, but also unintentional mistakes or misjudgments. To compensate for estimation and reporting risks, investors demand a risk premium (Healy \& Palepu 2001). It results from parameters of two overlaying distributions: one capturing possible payoffs from the business model and the other representing reporting risk ((Coles et al. 1995), p. 347). Owing to a steady processing and assessing of disclosed information, investors will frequently update their estimation concerning the distribution of future net cash flows, their perceived reporting risk and as a consequence their stipulated risk premiums.

Regulators address investors' risks in two ways. First, they require more informative disclosures, for example information oriented reporting standards, additional segment information or disclosure of compensation structure. Second, regulators introduce a higher level of enforcement, for instance by increasing independence of enforcement institutions or by tightening controls and sanctions. A higher level of mandatory disclosure regulation will create a higher level of information and reduces the perceived estimation as well as reporting risk. Enforcement regulation ensures regulatory compliance and particularly addresses reporting risk.

\subsection{A Model for the Relationship between Disclosure, Enforcement and Equity Valuation}

Most studies embed the concept of disclosure and enforcement regulation in a principal agent setting and see regulation only as a means to mitigate information asymmetries. In such a setting, disclosure lowers information asymmetry and therefore lowers the investors' perceived risk. Enforcement also reduces the principal's risk with similar effects. However, the principal-agent setting underplays the fundamental role of assessing the firm's business model. A higher level of mandatory disclosure regulation may not only have positive effects, but can also cause negative valuation effects by bringing more bad news to the fore. As an example, (White 2015) shows the arrival of bad news due to more fair value estimates in the course of FASB and IASB projects. This discovery of bad news can be a driver of negative valuation effects, and it can explain country-specific adverse effects despite higher levels of disclosure. Enforcement, to the contrary, increases information content and truthfulness and cannot, in isolation, have adverse valuation effects.

Using the concept of estimation risk and reporting risk instead of a simple principal-agent-setting to link regulation and valuation gives the following: higher levels of disclosure and enforcement regulation improve the quality of accounting information and lead to less incomplete, imprecise und uncertain information. Investors assess the business model and the reporting quality depending on the level of disclosures and the enforcement system. They update their beliefs and therefore adjust their estimations concerning the distributions of future net cash flows and the required risk premiums. Updates can change the estimations in a favorable or an unfavorable direction. Equity valuation as the investors' overall assessment of a firm, which incorporates all risks, serves as an observable measure for the impact of the trigger variables. The directed acyclic graph in Figure 1 sketches out the argument. In the following we discuss the influence of disclosure and enforcement regulation on the linking elements respectively. 


\section{Figure 1: A Model for Disclosure, Enforcement and Equity Valuation}

This directed acyclic graph shows the relation between disclosure and enforcement regulation and the valuation of equity. Elements are connected to pairs by arrows. Arrows are directed and therefore represent causal links between two elements. If there is a positive or negative effect is indicated by plus and/or minus signs.

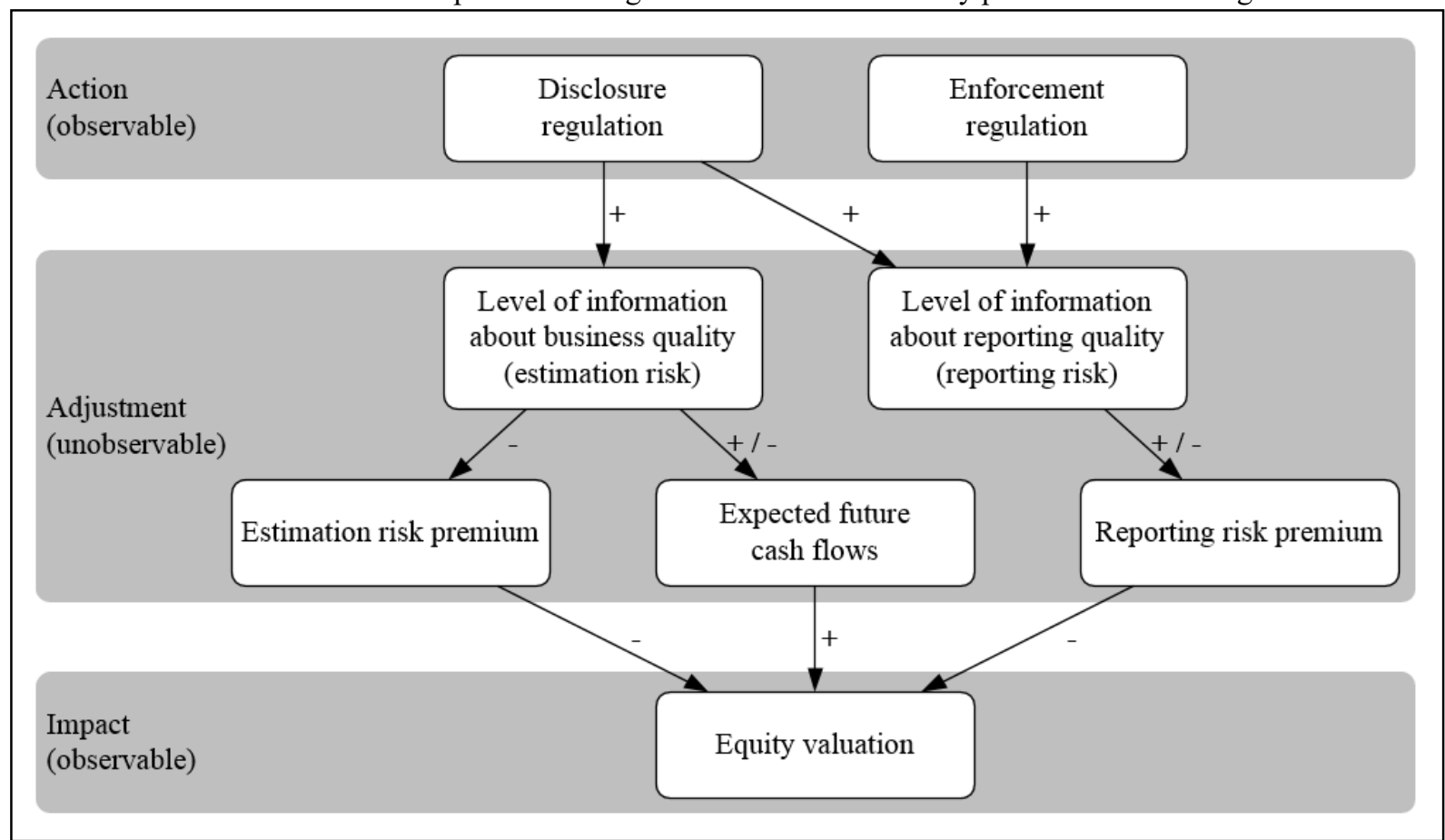

Level of information about business quality (estimation risk)

The level of information about the business quality captures the degree to which investors are able to assess the distribution of future cash flows from the underlying business. Investors face estimation risk, which arises from incomplete and imprecise information. Higher levels of disclosures reduce the perceived estimation risk as the information becomes more complete and precise. The causal link between disclosure level and estimation risk in Figure 1 is based on the analytical assumption that all information could be given to investors is free from distortion. As a consequence, enforcement, which addresses regulatory compliance, does not affect this link.

A change in disclosure regulation triggers adjustments in the estimation of future cash flows and the stipulation of risk premiums. This argument is empirically well documented: by means of changes in accounting standards as well as additional disclosure policies like ad-hoc announcements, quarterly and segment reports, the precision and quantity of public available information can be positively influenced, and disclosure environment becomes more and more informative ((Easley \& O'Hara 2004), p. 1578). A more informative disclosure environment leads to more accurate and less biased forecasts ((Basu et al. 1998), p. 1243). This is the result of investors updating previously estimated parameters of mean value and variance of future net cash flows. Updating can explain the increasing accuracy of analysts' earnings forecasts with the introduction of IAS/IFRS (e.g. (Ashbaugh \& Pincus 2001); (Byard et al. 2011); (Horton et al. 2013); (Jiao et al. 2012); (Tan et al. 2011)) and, more generally, with an augmented level of annual report disclosures (e.g. (Hope 2003); (Lang \& Lundholm 1996)).

While the perceived estimation risk and therefore the stipulated risk premium always decreases owing to a more informative disclosure environment ((Barry \& Brown 1985), p. 420; (Hail \& Leuz 2006), p. 487), the expected mean value of future net cash flows can move in either direction depending on the content of newly disclosed information and previous estimation. Already (Richardson \& Welker 2001) pointed out that especially the content of disclosures must play a role, not only the level of information. Additional mandatory disclosure regulation leading to more good news means that the expectations about future net cash flows will be adjusted upwards. Higher mandatory disclosure regulation incorporating more bad news leads to a downward shift of the expected mean value of the distribution of cash flows.

In terms of the adjustment of the expected mean value of future net cash flows, one can distinguish into two groups of firms. The first group voluntarily discloses all (good and bad) news immediately. Accordingly, this group obtains solely positive effects from additional mandatory disclosure regulation. The second group of firms tends to withhold bad news while good news are disclosed immediately. Various reasons for withholding bad news are provided by (Kothari et al. 2009). A higher level of mandatory disclosure regulation brings these bad news to the fore, because firms are no longer able to withhold them. As a consequence, investors adjust the expected mean value of future net cash flows downwards for these firms, which leads to negative valuation effects. The negative 
valuation effects of this adjustment may exceed the positive effects of a more informative disclosure environment with more precision, transparency and comparability on firm level.

The introduction of additional business segment information can serve as an example. Without business segment information there is an overlay of information between the different segments. Additional business segment information enables investors to get a more detailed view about business dynamics. As a result of the more detailed view, the risk premium for the bearing of estimation risk decreases, which leads, ceteris paribus, to a higher valuation. Investors also use this information to update their prior estimated mean value of expected future cash flows. It could be good news, which leads to a shift upwards, or additional information may be bad news and signal low growth or a poor product pipeline, which will shift the expected mean value downwards. The positive effects of a lower estimation risk premium then may very well be overcompensated by the negative effects from lower estimated future net cash flows.

Level of information about reporting quality (reporting risk)

The level of information about reporting quality describes the degree to which investors are able to assess the credibility of information provided by the firm. Investors have to process reporting risk, which is driven by uncertainty about the truthfulness of information. Higher levels of disclosure and enforcement regulation influence the perceived reporting risk. While the link between enforcement and reporting risk is straightforward, there are at least three effects from the influence of disclosure regulation on reporting risk. The first two unequivocally lead to lower reporting risk premiums; for the third the outcomes are unclear.

The first effect rests on monitoring costs. Disclosures of compensation structure, large shareholdings, inside ownership or transactions with related parties strengthens the position of investors concerning the detection of insider trading, earnings management and excessive compensations ((Healy \& Palepu 2001); (Meser et al. 2015)). As a result, investors can better monitor if managers take actions that are congruent with shareholder's interests. Lower monitoring costs will reduce the perceived reporting risk and results in falling reporting risk premiums (Lombardo \& Pagano 2002).

Second, disclosure regulation concerning transactions and inside ownership gives a hint to investors if managers believe that a security is undervalued or overvalued. Hence, investors are better informed about the quality of reporting; they are able to better assess if reporting can give a true and fair view of assets, financial and earnings position. As a consequence, investors update their stipulated reporting risk premiums for the lower perceived reporting risk downwards.

Third, while investors update their valuations because of immediate changes in disclosure regulation, the reason for their updating influences their assessment of reporting risk. If newly disclosed information (see the example of the disclosure of segment information) confirms that past valuations of assets and liabilities have been appropriate, investors will interpret this as a positive signal. However, it is also conceivable that a higher disclosure exposes shortcomings in past reports. For instance, mistakes of the past or non-communicated risks are subsequently and belatedly made public. Surprises, good or bad, shift the reporting risk premium upwards. The perceived higher reporting risk, ceteris paribus, leads to a lower equity valuation. Higher mandatory disclosure levels can therefore have either a positive or a negative effect on the reporting risk premium.

The argument with respect to enforcement is unambiguous: higher levels of enforcement always show positive valuation effects at firm level. Better control mechanisms, for instance proactive reviews, or more effective deterrence for managers lead to updated expectations relating to the likelihood of detection of intentional and unintentional mistakes in disclosed information (Ernstberger et al. 2012). As a result, the level of information about reporting quality rises and the reporting risk premiums fall. Empirically, this was emphasized by (Bhattacharya \& Daouk 2002), (Bushee \& Leuz 2005) and (Ernstberger et al. 2012). Moreover, the credibility of the deterrence mechanism remains a necessary condition for the functioning of enforcement ((Dasgupta 2000), p. 49). A higher independence of enforcement institutions leads to more credibility and lower reporting risk premium. As a consequence, a higher level of enforcement regulation can - given credible mechanisms - only lead to higher equity valuations. Of course, our model presupposes that there is always a minimum level of disclosure and enforcement regulation. Without a minimum level of enforcement regulation, a higher level of disclosure regulation will not have an impact on equity valuation and vice versa.

The model suggests an ambiguous effect for mandatory disclosure regulation and an unambiguous effect for enforcement regulation on the basis of the information environment. Our framework provides theoretical explanations for different individual positive and negative equity valuation effects. If additional mandatory disclosure uncovers more bad news, negative valuation effects may exceed the positive valuation effects in total at the firm level. At the country level, negative valuation effects do not arise uniformly. We assume differences between countries' valuation effects to be caused by the heterogeneity of firms' disclosures, and varying countryspecific valuation effects depend on the proportion of good and bad news firms.

Costs arising from regulation may blur this picture (Leuz \& Wysocki 2016). Costs may adversely affect firm valuations when investors believe that costs borne by the average firm outweigh the benefits. Following this argument, increasing enforcement regulation could also have adverse effects on the valuation. This point, however, 
cannot be empirically particularly virulent. At the country level, which we will analyze in the following, this adverse cost-benefit-effect would have to hold for the average firm. Unlike many transnational disclosure regulations such as IFRS, enforcement regulation still happens at the national level. In the aggregate, adverse costbenefit-settings would mean that the national regulator has misestimated the regulatory effect for the average firm. This seems, in particular given the deliberative processes in the run-up to new regulation, unlikely. We also believe that this argument holds for disclosure regulation given the size and importance of the countries analyzed in our sample. While smaller countries may be hurt by adverse effects from transnational regulation, this effect on the average firm in our sample seems unlikely, especially since in most cases mandatory disclosure regulation require information that is already available or will be easily produced ((Ben-Shahar \& Schneider 2014), p. 3). We are therefore confident mainly to assess changes in the information environment.

\section{Leximetric Analysis of Disclosure and Enforcement for a Six Country Case}

To investigate econometrically the relationship between disclosure, enforcement and equity valuation, it is first necessary to quantify the elements of disclosure and enforcement regulation. Researcher-constructed indices use leximetric analysis and aggregate the relevant rules into one score. It has been used to investigate the influence of securities regulation on capital markets in certain industries (e.g. (Botosan 1997); (Wiseman 1982)), in particular countries (e.g. (Meser et al. 2015)) or for cross-country comparisons (e.g. (Cooke \& Wallace 1990); (Daouk et al. 2006); (Eleswarapu \& Venkataraman 2006); (Hail \& Leuz 2006); (La Porta et al. 2006)).

While most models are static or focus either on disclosure or enforcement regulation, we quantify both components and their changes over time. We use the index of (Meser et al. 2015) for the German market and extend it to further markets of our sample. The index has the advantage to use only information that is publicly available, and it scores items which had empirical relevance in prior studies on capital market effects of disclosure and enforcement regulation.

The disclosure score consists of Financial Disclosures and Governance Disclosures. The first category contains the items Information Accounting, Material Information, Quarterly Reports, Management Commentary and Segment Information and represents the main information source for investors (for prior evidence see, inter alia, (Aitken et al. 1994); (Cole \& Jones 2004); (Landsman \& Maydew 2002); (Leuz \& Verrecchia 2000); (Muntermann \& Guettler 2007)). The category Governance Disclosures deals with disclosures that allow the principal to monitor the agent's actions. It comprises the items Compensation, Inside Ownership, Prospectus, Shareholders and Transactions (for prior evidence see, inter alia, (Bushman et al. 2004); (Hail \& Leuz 2006); (La Porta et al. 2006)).

Enforcement is captured in the categories Independence and Scope. The first category represents the degree of independence of regulatory institutions and incorporates the items Appointment, Focus, Rule-Making Power and Tenure in line with (La Porta et al. 2006) and Auditor Independence according to (Krishnamurthy et al. 2006). The second category Scope is about all instruments that help regulatory institutions to detect and sanction misbehavior. It includes the items Document, Witness, Sanctions Company, Sanctions Management and Sworn Statement, which are also already used in past studies (e.g. (Engel et al. 2007); (La Porta et al. 2006)). Our study replaces the item Witness by the item Review, because of the similarity to the item Document, a higher relevance and better aptitude to approximate enforcement regulation. An overview and detailed description of all score items is presented by the following Table 1 . 
Table 1: Description of the Regulation Score

This table describes the items that are used for the country-specific regulation score. It is separated into a disclosure score (Panel A) and an enforcement scores (Panel B).

\begin{tabular}{|c|c|}
\hline \multicolumn{2}{|c|}{ Panel A: Disclosure Score } \\
\hline Score Items & Description \\
\hline \multicolumn{2}{|l|}{$\begin{array}{l}\text { Financial } \\
\text { Disclosures }\end{array}$} \\
\hline $\begin{array}{l}\text { D1: Information } \\
\text { Accounting }\end{array}$ & $\begin{array}{l}\text { Equals } 1 \text { if companies are required to follow international accounting standards for } \\
\text { their consolidated financial statements; equals } 0.5 \text { if companies have the choice } \\
\text { between local GAAP and international accounting standards; equals } 0 \text { otherwise. }\end{array}$ \\
\hline $\begin{array}{l}\text { D2: Management } \\
\text { Commentary }\end{array}$ & $\begin{array}{l}\text { Rating for the complexity of the Management Discussion and Analysis (MD\&A, as it } \\
\text { is named in the US; e.g. in the UK it is named Operating and Financial Review, in } \\
\text { Germany Lagebericht). Equals } 1,0.75,0.5,0.25 \text { or if no such report exists } 0 \text {. }\end{array}$ \\
\hline $\begin{array}{l}\text { D3: Material } \\
\text { Information }\end{array}$ & Equals 1 if companies are required to pursue ad hoc disclosure; equals 0 otherwise. \\
\hline $\begin{array}{l}\text { D4: Quarterly } \\
\text { Reports }\end{array}$ & $\begin{array}{l}\text { Equals } 1 \text { if companies are required to publish quarterly reports; equals } 0.5 \text { if reports } \\
\text { have to be published semi-annually; equals } 0 \text { otherwise. }\end{array}$ \\
\hline $\begin{array}{l}\text { D5: Segment } \\
\text { Information }\end{array}$ & $\begin{array}{l}\text { Equals } 1 \text { if companies are required to publish detailed information on business } \\
\text { segments and regional segments; equals } 0.5 \text { if companies are free to choose the } \\
\text { extent of segment information disclosure; equals } 0 \text { otherwise. }\end{array}$ \\
\hline \multicolumn{2}{|l|}{$\begin{array}{l}\text { Governance } \\
\text { Disclosures }\end{array}$} \\
\hline D6: Compensation & $\begin{array}{l}\text { Equals } 1 \text { if companies are required to disclosure total compensation of each top } \\
\text { manager; equals } 0.5 \text { if regulation only requires the disclosure of the aggregate } \\
\text { compensation of top management; equals } 0 \text { otherwise. }\end{array}$ \\
\hline $\begin{array}{l}\text { D7: Inside } \\
\text { Ownership }\end{array}$ & $\begin{array}{l}\text { Equals } 1 \text { if firms are required to disclose the number of shares owned by each } \\
\text { member of the management; equals } 0.5 \text { if regulation only requires the aggregate } \\
\text { number of the shares owned by the management to be disclosed; equals } 0 \\
\text { otherwise. }\end{array}$ \\
\hline D8: Prospectus & $\begin{array}{l}\text { Equals } 1 \text { if companies are required to set up a prospectus for potential investors on } \\
\text { any public offering; equals } 0.5 \text { if there exist material exemptions from publishing a } \\
\text { prospectus, e.g. regarding tender size; equals } 0 \text { otherwise. }\end{array}$ \\
\hline D9: Shareholders & $\begin{array}{l}\text { Equals } 1 \text { if companies are required to disclose details (e.g. name, share property) of } \\
\text { shareholders that directly or indirectly control at least } 10 \% \text { of the company's stock; } \\
\text { equals } 0.5 \text { if regulation only requires the disclosure of the direct or aggregate } \\
\text { ownership of these shareholders; equals } 0 \text { otherwise. }\end{array}$ \\
\hline D10: Transactions & $\begin{array}{l}\text { Equals } 1 \text { if companies are required to disclosure all capital market transactions that } \\
\text { involve related parties; equals } 0.5 \text { if only some transactions between the company } \\
\text { and related parties have to be disclosed; equals } 0 \text { otherwise. }\end{array}$ \\
\hline $\begin{array}{l}\text { Disclosure Score } \\
\text { Value }\end{array}$ & the average of items D1 to D10 and ranges between 0 and 1 \\
\hline
\end{tabular}


Table 1, continued

Panel B: Enforcement Score

\begin{tabular}{|c|c|}
\hline Score Items & Description \\
\hline \multicolumn{2}{|l|}{ Independence } \\
\hline E1: Appointment & $\begin{array}{l}\text { Equals } 1 \text { if the executive board members of the enforcement agency at the state or } \\
\text { federal level (hereinafter termed "the Enforcement Institution") are not exclusively } \\
\text { appointed by the executive (e.g. the government or any other executive institution); } \\
\text { equals } 0 \text { otherwise. }\end{array}$ \\
\hline $\begin{array}{l}\text { E2: Auditor's } \\
\text { Independence }\end{array}$ & $\begin{array}{l}\text { Equals } 1 \text { if substantial laws concerning the independence of auditors are } \\
\text { established; equals } 0.5 \text { if there are only weak independence criteria; equals } 0 \\
\text { otherwise. }\end{array}$ \\
\hline E3: Focus & $\begin{array}{l}\text { Equals } 1 \text { if separate government agencies or official authorities are in charge of } \\
\text { supervising commercial banks and stock exchanges; equals } 0 \text { otherwise. }\end{array}$ \\
\hline $\begin{array}{l}\text { E4: Rule-making } \\
\text { Power }\end{array}$ & $\begin{array}{l}\text { Equals } 1 \text { if the Enforcement Institution can establish regulations on public offerings } \\
\text { and stock exchange listing rules without approval from other governmental } \\
\text { institutions; equals } 0.5 \text { if the Enforcement Institution can establish regulations on } \\
\text { public offerings and stock exchange listing rules only with approval from other } \\
\text { governmental institutions; equals } 0 \text { otherwise. }\end{array}$ \\
\hline E5: Tenure & $\begin{array}{l}\text { Equals } 1 \text { if the governmental authority that appoints members of the Enforcement } \\
\text { Institution does not have the power to dismiss them; equals } 0 \text { otherwise. }\end{array}$ \\
\hline \multicolumn{2}{|r|}{ ( } \\
\hline E6: Document & $\begin{array}{l}\text { Equals } 1 \text { if the Enforcement Institution has the legal power to demand documents } \\
\text { from all persons that are related to the suspicious firm; equals } 0.5 \text { if the } \\
\text { Enforcement Institution has the legal power to only demand documents from the } \\
\text { directors of suspicious publicly-traded corporations; equals } 0 \text { otherwise. }\end{array}$ \\
\hline E7: Review & $\begin{array}{l}\text { Equals } 1 \text { if the Enforcement Institution requires a continuous filing of disclosure } \\
\text { documents and submits them to a systematic, proactive and reactive review; equals } \\
0.5 \text { if a filing and only a reactive review is statutory, equals } 0 \text { otherwise. }\end{array}$ \\
\hline $\begin{array}{l}\text { E8: Sanctions } \\
\text { Company }\end{array}$ & $\begin{array}{l}\text { Equals } 1 \text { if the Enforcement Institution has far reaching competencies to impose } \\
\text { financial and other legal penalties against companies; equals } 0.5 \text { if the Enforcement } \\
\text { Institution can only impose financial penalties; equals } 0 \text { otherwise. }\end{array}$ \\
\hline $\begin{array}{l}\text { E9: Sanctions } \\
\text { Management }\end{array}$ & $\begin{array}{l}\text { Equals } 1 \text { if accountants/managers can be held criminally liable when they are } \\
\text { unaware of fraud and misleading information; equals } 0.5 \text { if the } \\
\text { accountants/managers can be held criminally liable when they are aware that the } \\
\text { financial statements are misleading; equals } 0 \text { otherwise. }\end{array}$ \\
\hline $\begin{array}{l}\text { E10: Sworn } \\
\text { Statement }\end{array}$ & $\begin{array}{l}\text { Equals } 1 \text { if the directors have to sign for the material accuracy of financial } \\
\text { statements; equals } 0 \text { otherwise. }\end{array}$ \\
\hline $\begin{array}{l}\text { Enforcement } \\
\text { Score Value }\end{array}$ & E10 and ranges between 0 and \\
\hline
\end{tabular}

With the exception of Management Commentary, which allows a differentiation between five levels, all items can take values of $0,0.5$ and 1 , where 1 represents the highest regulatory activity. Score values change in time series whenever a new regulatory measure becomes effective. We consider all mandatory changes in disclosure and enforcement regulation. The overall score values are calculated as the average of the ten items and ranges between 0 and 1 . We choose this equal weighting of score items to avoid subjective bias.

In the following, we analyze disclosure and enforcement regulation for the six countries (ordered by market size): U.S., Japan, UK, Germany, France and Canada between 1991 and 2010. We review all relevant rules, regulations and competences in the six countries to classify mandatory disclosure requirements and their enforcement, but we do not distinguish between a country's stock market segments as there are only small regulatory differences between the segments within a country. The appendix provides a detailed analysis of the country-specific score values and their changes over time for the six country cases.

The results of the leximetric analysis of the six countries can be compared in the easiest and most illustrative way by charting their yearly score values for disclosure and enforcement regulation, as presented in Figures 2 and 3. Three observations are apparent: First, mostly upward changes can be observed. Only the enforcement scores of Japan and the UK decrease, albeit temporarily. Our leximetric analysis adds further evidence that regulators around the world tighten the screw on disclosure and enforcement regulation. Second, especially the years after the enactment of the SOX are characterized by more frequent and steeper increases. Third, and not astonishingly, the U.S. are setting the pace for all other five countries. Even Germany and Japan, with mostly low score values, 
dramatically catch up after 2003.

Figure 2: Development of the disclosure scores in a cross country comparison

This figure shows the development of the disclosure scores for the U.S., Japan, UK, Germany, France and Canada in comparison for the period between 1991 and 2010. The score ranges between 0 and 1, and is calculated as the average of ten variables capturing the independence and scope of an enforcer as described in Panel B of Table 1.

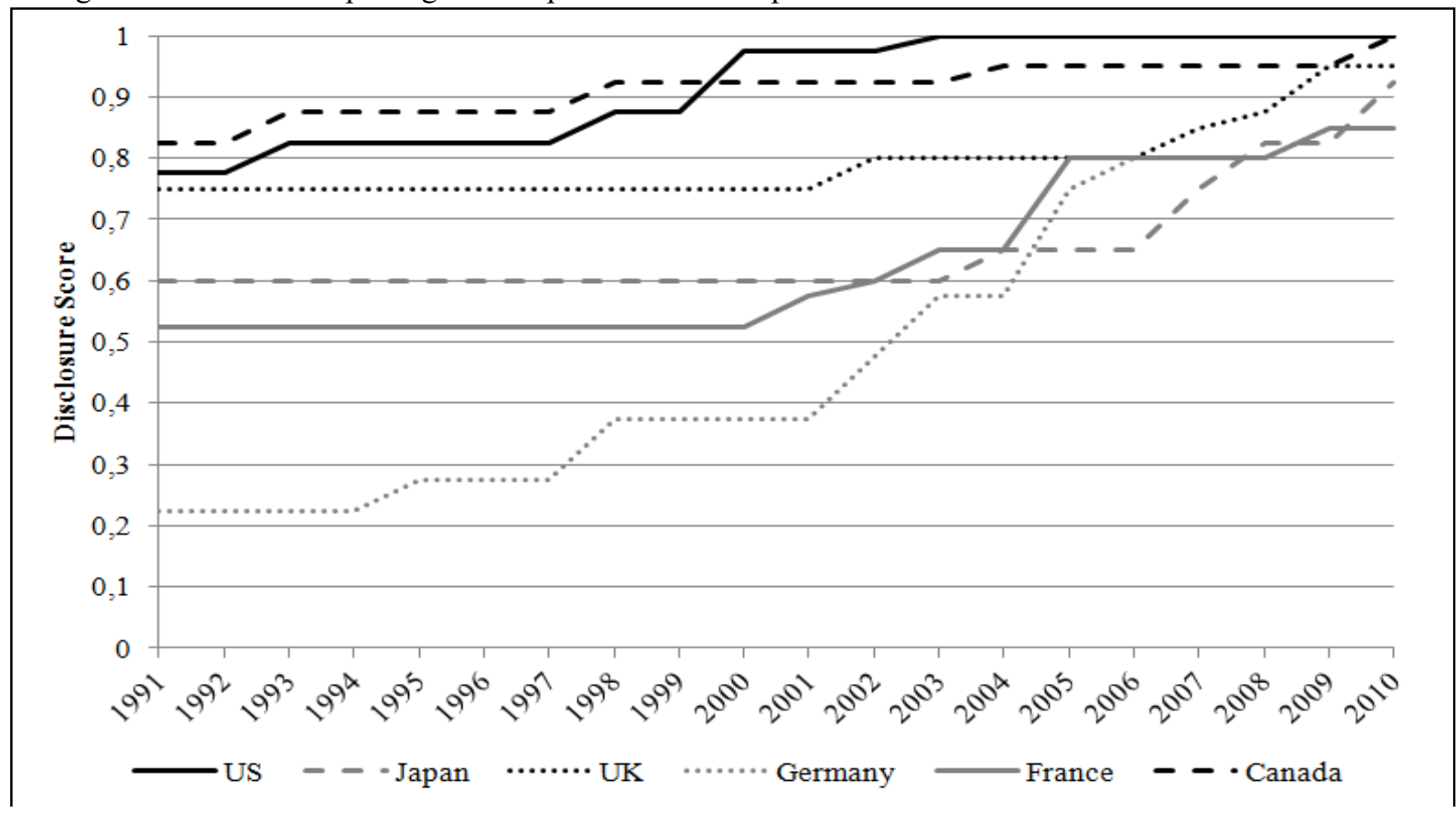

Figure 3: Development of the enforcement scores in a cross country comparison

This figure shows the development of the enforcement scores for the U.S., Japan, UK, Germany, France and Canada in comparison for the period between 1991 and 2010. The score ranges between 0 and 1, and is calculated as the average of ten variables capturing financial disclosures and governance disclosures as described in Panel A of Table 1 .

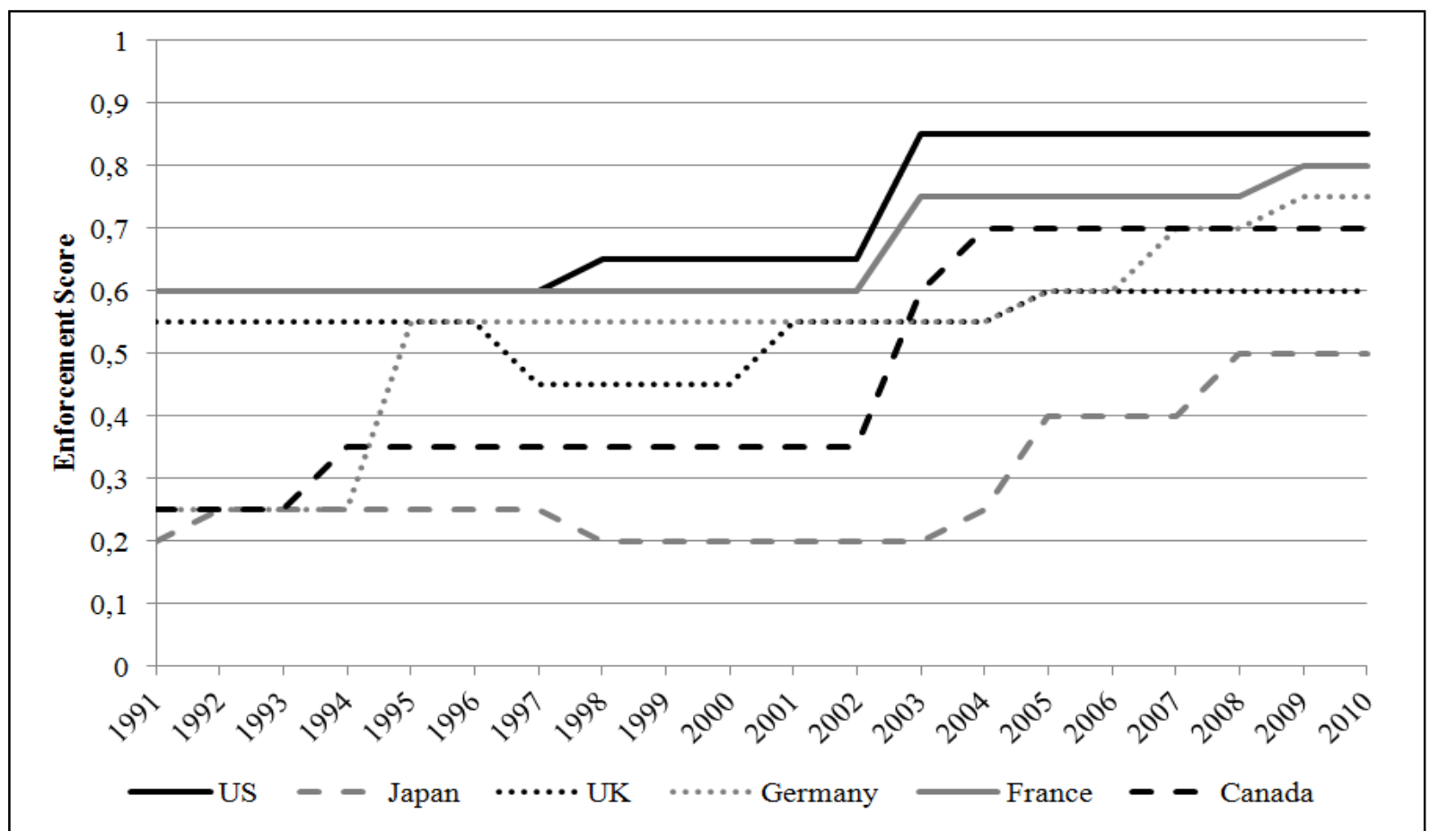




\section{Empirical Analysis}

\subsection{Model Specification}

Following previous literature (e.g. (Daske et al. 2008), (Ernstberger et al. 2012); (Meser et al. 2015)), we perform panel ordinary least square (OLS) regressions with robust standard errors clustered by firm. We regress our three proxies for valuation effects $\left(V A L_{i t}\right)$, namely Tobin's Q $\left(L N T O B I N_{i t}\right)$, the market-to-book ratio $\left(L N M T B_{i t}\right)$ and a valuation factor $\left(V A L . F A C_{i t}\right)$, on the yearly disclosure and enforcement score value and on various firm and country specific controls. We formulate the following equitation (1):

$V A L_{i t}=\beta_{0}+\beta_{1} D I S C_{t}+\beta_{2} E N F O_{t}+\beta_{3} L N S S I Z E_{i t}+\beta_{4} L E V_{i t}+\beta_{5} R O A_{i t}+\beta_{6} A G_{i t}+\beta_{7} G D P_{t}+\beta_{7} D_{t}+\eta$

We compute Tobin's $Q$ as the sum of total assets and the market value of equity minus the book value of equity, scaled by total assets. The market-to-book ratio is calculated as the yearly average market capitalization divided by the book value of common equity at the end of the fiscal year. In line with other studies, we apply principal component analysis and combine our variables into an additional valuation factor since a factor constitutes a more reliable metric to approximate security's valuation (see e.g. (Ernstberger et al. 2012) and (Christensen et al. 2013)).

Following our theoretical framework provided in section 2, enforcement regulation is expected to be positively associated with equity valuation. For mandatory disclosure regulation, we have identified various positive and negative individual effects in our framework. In an empirical setting, it is not possible to isolate and measure the amount of these individual effects of mandatory disclosure regulation on equity valuation. Only the total effect can be observed. With regard to our model, we expect varying country-specific total valuation effects depending on the proportion of good and bad news firm within the countries.

For our six country sample, we predict the predominance of firms withholding bad news for Japan and France. In Japan, informal communication mechanisms and low enforcement score values throughout our observation period may indicate more inherited burdens in the balance sheets of Japanese firms. Famous examples for inherited burdens are scandals around Toshiba and Olympus. Already (Leuz et al. 2003) provide empirical evidence that there is more earnings management in firms based in insider economies with low enforcement mechanisms. A tendency to earnings management can be interpreted as a signal that these firms also tend to withhold bad news. In the course of a higher level of mandatory disclosure regulation these bad news must be uncovered. As a consequence, we expect a negative coefficient for mandatory disclosure regulation in Japan.

Regarding France, the prediction of a proportion towards more bad news firms is reasoned by macroeconomic structural deficits. The need for structural reforms in France and the existence of powerful labor unions are problems on country level that are financially reflected in the balance sheets on firm level. For example, strikes in France led to the highest amount in Europe of non-work days per 1,000 employees throughout the observation period (Data from European Trade Union Institute; see e.g. (Carley 2010)). This is only one example for higher costs and decline in sales for French firms.

We select control variables in line with similar studies (see (Daske et al. 2008); (Meser et al. 2015)). In particular, to control for non-regulatory company effects, we include the following control variables: total assets $\left(S I Z E_{i t}\right)$, financial leverage $\left(L E V_{i t}\right)$, return on assets $\left(R O A_{i t}\right)$ and the asset growth rate $\left(A G_{i t}\right)$. In addition, we incorporate the gross domestic change rate (in real terms; $G D P_{t}$ ) and a dummy variable for the technical effects from the mandatory introduction of information accounting $\left(D_{t}\right)$ as country specific controls. All other firm specific aspects are captured by firm fixed effects. A definition of all measurement and control variables is shown in Table 2. 


\section{Table 2: Variable Definitions}

This table shows variable definitions for all variables used in the regressions. For all independent variables expected signs are given. All variables are winsorized at the extreme percentiles, except for those with natural boundaries at both ends.

\begin{tabular}{|c|c|c|}
\hline \multicolumn{3}{|c|}{ Panel A: Measurement Variables } \\
\hline \multicolumn{2}{|l|}{$L N_{-} T O B I N_{i t}$} & $\begin{array}{l}\text { natural logarithm of total assets plus market value of equity as of seven months after } \\
\text { the end of fiscal year } t \text { minus book value of common equity for firm } i \text {, scaled by total } \\
\text { assets }\end{array}$ \\
\hline \multicolumn{2}{|l|}{$L N \_M T B_{i t}$} & $\begin{array}{l}\text { natural logarithm of the average market capitalization in fiscal year } t \text { for firm } i \text {, } \\
\text { divided by book value of common equity }\end{array}$ \\
\hline \multicolumn{3}{|c|}{ Panel B: Control Variables } \\
\hline$D I S C_{t}$ & $+/-$ & $\begin{array}{l}\text { country-specific disclosure score value in calendar year } t \text { as described in Table } \\
2-7 \text {; }\end{array}$ \\
\hline$E N F O_{t}$ & + & $\begin{array}{l}\text { country-specific enforcement score value in calendar year } t \text { as described in Table } 2 \text { - } \\
7 \text {; }\end{array}$ \\
\hline$L N \_S I Z E_{i t}$ & $+/-$ & natural logarithm of total assets in fiscal year $t$ for firm $i$; \\
\hline$L E V_{i t}$ & + & total liabilities divided by total assets in fiscal year $t$ for firm $i$ \\
\hline$R O A_{i t}$ & + & net income divided by lagged total assets in fiscal year $t$ for firm $i$; \\
\hline$A G_{i t}$ & + & asset growth rate in fiscal year $t$ for firm $i$ \\
\hline$G D P_{t}$ & + & country-specific gross domestic product change rate in real terms of calendar year $t$; \\
\hline$D_{t}$ & $+1-$ & $\begin{array}{l}\text { country-specific dummy variable that captures technical effects from the mandatory } \\
\text { introduction of information accounting in calendar year } t \text {. }\end{array}$ \\
\hline
\end{tabular}

For firm size we predict no sign. Small firms, for instance, will be more likely to have growth opportunities ((Lang et al. 2004), p. 612), and large firms are likely to be less risky and therefore have lower cost of capital ((Botosan 1997), p. 341). Because of pecking order theory, we predict a positive sign for leverage ((Frank \& Goyal 2003)). For the return on assets and the asset growth rate we expect positive coefficients. To control for macroeconomic events and time effects, we include the gross domestic change rate, for which we expect a positive correlation ((Levine \& Zervos 1998)). We incorporate a dummy variable for the technical effects from the mandatory adoption of information accounting to our regression. This dummy catches the effect that information accounting does not only lead to a change in the information environment, but also affects the valuation of balance sheet items technically by recognizing hidden reserves in countries that previously emphasized prudence. Higher book values of equity and an increased balance sheet total affect our valuation metrics. We control for this effect in Germany and France. For the UK, we do not consider the information accounting effect in 2005 because of the similarity of UK GAAP to IFRS ((Bae et al. 2008); (Brochet et al. 2013), p. 1373).

We winsorize all variables at the extreme percentiles except for those with natural boundaries at both ends. According to previous empirical studies, we use the logarithm for our valuation metrics as well as for the firm size (e.g. (Daske et al. 2008); (Fu et al. 2012); (Meser et al. 2015)). As a result, by using logarithms we are able to capture non-linear relations better, to correct for heteroskedasticity and also to compress data to give less weight to outliers.

\subsection{Sample Selection and Descriptive Statistics}

As disclosure requirements do not equally affect all listed firms, we only consider firms that are listed on regulated domestic markets. Our initial data sample consists of all companies that have been listed on a regulated domestic market in one of our six sample countries. We treat the following stock exchanges or indices as regulated markets: NYSE, AMEX, NASDAQ and OTCBB in the U.S.; the TSE First and Second Sections in Japan; the FTSE AllShare in the UK; the CDAX in Germany; the CAC All-Share in France and the TSX Composite and TSX Venture Composite in Canada. As OTCBB has not been enforced by the SEC for the whole sample period (until 1999), we performed a robustness check without this market and arrived at similar results. We retrieve accounting and daily stock market data from Datastream/Worldscope for a maximum sample period from 1980 to 2010. Since data availability is extremely limited for all years before 1991, we constrain our sample for the main analysis to the 20year period of the fiscal years 1991 to 2010 . We eliminate financial firms because they are subject to further special regulations. In addition, we delete observations with abbreviated financial years. We do not delete dead firms or firms that do not provide data for the entire observation period for survivorship bias reasons. Further, we only use 
observations that have data for each of our specifications. We do so to ensure comparability across our models. Especially for the equity markets of Canada and the UK, data availability notably constrains the sample. We end up with a cross-country sample of 92,211 firm-year observations.

\subsection{Results}

We proceed as follows. We first present a pooled cross-country regression. To examine the influence of the legal system on valuation effects with regard to (Armstrong et al. 2010), we will then divide our sample into two subsamples: a common law country and a code law country group. The U.S., UK and Canada are common law countries, while Japan, France and Germany are classified as code law countries (Nobes \& Parker 2012). Third, we investigate all six countries separately to show that varying valuation effects are country-specific.

The three left-hand columns of Table 3 report results from regressing valuation metrics on disclosure and enforcement regulation and control variables for the pooled sample. Column 1 shows that our valuation model accounts for $59 \%$ of the variation in Tobin's Q. Our second and third pooled valuation regressions, namely marketto-book ratio and the valuation factor, exhibit similar results, yielding an adjusted $R^{2}$ value of $60 \%$ and $66 \%$ respectively. We find a significantly negative coefficient for disclosure regulation in two of three regressions indicating that mandatory disclosure regulation is negatively associated with firm valuation. In terms of our theoretical model, the uncovering of bad news must, in the pooled sample, outweigh the positive effects. For enforcement regulation we find the predicted positive coefficient in all regressions. The signs of all control variables are as predicted. The respective magnitudes of the coefficients cannot be further interpreted or compared in the model setup. As an untabulated robustness check we also include country fixed effects into the pooled regression and arrive at similar results.

\section{Table 3: Regression Results for Securities Market Regulation - Pooled Regression, Common Law and} Code Law Group

This table reports coefficients and $t$ values in parentheses of two-tailed tests (with significances at the $10 \%, 5 \%$ and $1 \%$ levels indicated by $*, * *$ and $* * *)$ of the following panel ordinary least square (OLS) regressions with firm fixed effects and robust standard errors clustered by firm:

$$
V A L_{i t}=\beta_{0}+\beta_{1} D I S C_{t}+\beta_{2} E N F O+\beta_{3} L N \_S I Z E_{i t}+\beta_{4} L E V_{i t}+\beta_{5} R O A_{i t}+\beta_{6} A G_{i t}+\beta_{7} G D P_{t}+\beta_{7} D_{t}+\eta
$$

Please refer to Table 2 for variable definitions. $L N$ corresponds to the natural logarithm. Intercepts remain unreported for the sake of brevity.

\begin{tabular}{|c|c|c|c|c|c|c|c|c|c|c|c|c|c|c|c|c|c|c|}
\hline \multirow[b]{3}{*}{$\overline{D I S C_{t}}$} & \multicolumn{6}{|c|}{ ALL COUNTRIES } & \multicolumn{6}{|c|}{ COMMON LAW-COUNTRIES } & \multicolumn{6}{|c|}{ CODE LAW-COUNTRIES } \\
\hline & \multicolumn{2}{|c|}{$L N_{-} T O B I N_{i t}$} & \multicolumn{2}{|l|}{$L N \_M T B_{i t}$} & \multicolumn{2}{|c|}{ VAL.FAC $i t$} & \multicolumn{2}{|c|}{$L N \_T O B I N_{i t}$} & \multicolumn{2}{|l|}{$L N \_M T B_{i t}$} & \multicolumn{2}{|c|}{ VAL.FAC } & \multicolumn{2}{|c|}{$L N \_T O B I N_{i t}$} & \multicolumn{2}{|l|}{$L N \_M T B_{i t}$} & \multicolumn{2}{|l|}{ VAL.FAC $i t$} \\
\hline & $\begin{array}{l}-0.4286 \\
(0.000)\end{array}$ & **** & $\begin{array}{l}-0.4112 \\
(0.000)\end{array}$ & **** & $\begin{array}{l}-0.3677 \\
(0.000)\end{array}$ & $* * *$ & $\begin{array}{l}0.7695 \\
(0.000)\end{array}$ & $* * *$ & $\begin{array}{l}1.4739 \\
(0.000)\end{array}$ & $* * *$ & $\begin{array}{l}1.0187 \\
(0.000)\end{array}$ & $* * *$ & $\begin{array}{l}-0.6603 \\
(0.000)\end{array}$ & $* * *$ & $\begin{array}{l}-1.1399 \\
(0.000)\end{array}$ & $* * *$ & $\begin{array}{l}-0.8124 \\
(0.000)\end{array}$ & $* * *$ \\
\hline$E N F O_{t}$ & $\begin{array}{l}0.6978 \\
(0.000)\end{array}$ & $* * *$ & $\begin{array}{l}0.8431 \\
(0.000)\end{array}$ & $* * *$ & $\begin{array}{l}0.6624 \\
(0.000)\end{array}$ & $* * *$ & $\begin{array}{l}0.7197 \\
(0.000)\end{array}$ & $* * *$ & $\begin{array}{l}0.4858 \\
(0.000)\end{array}$ & $* * *$ & $\begin{array}{l}0.4955 \\
(0.000)\end{array}$ & $* * *$ & $\begin{array}{l}0.4508 \\
(0.000)\end{array}$ & $* * *$ & $\begin{array}{l}1.0540 \\
(0.000)\end{array}$ & $* * *$ & $\begin{array}{l}0.6739 \\
(0.000)\end{array}$ & ** \\
\hline$L N \_S I Z E_{i t}$ & $\begin{array}{l}-0.0765 \\
(0.000)\end{array}$ & $* * *$ & $\begin{array}{l}0.1205 \\
(0.000)\end{array}$ & $* * *$ & $\begin{array}{l}-0.0002 \\
(0.987)\end{array}$ & & $\begin{array}{l}-0.1250 \\
(0.000)\end{array}$ & $* * *$ & $\begin{array}{l}0.0667 \\
(0.000)\end{array}$ & *** & $\begin{array}{l}-0.0441 \\
(0.000)\end{array}$ & $* * *$ & $\begin{array}{l}-0.1049 \\
(0.000)\end{array}$ & *** & $\begin{array}{l}0.0553 \\
(0.074)\end{array}$ & * & $\begin{array}{l}-0.0430 \\
(0.049)\end{array}$ & ** \\
\hline$L E V_{i t}$ & $\begin{array}{l}0.2336 \\
(0.000)\end{array}$ & $* * *$ & $\begin{array}{l}1.0724 \\
(0.000)\end{array}$ & $* * *$ & $\begin{array}{l}0.6091 \\
(0.000)\end{array}$ & $* * *$ & $\begin{array}{l}0.0682 \\
(0.046)\end{array}$ & $* *$ & $\begin{array}{l}0.9156 \\
(0.000)\end{array}$ & $* * *$ & $\begin{array}{l}0.4646 \\
(0.000)\end{array}$ & $* * *$ & $\begin{array}{l}0.4331 \\
(0.000)\end{array}$ & $* * *$ & $\begin{array}{l}1.2623 \\
(0.000)\end{array}$ & $* * *$ & $\begin{array}{l}0.7875 \\
(0.000)\end{array}$ & $* * *$ \\
\hline$R O A_{i t}$ & $\begin{array}{l}0.4482 \\
(0.000)\end{array}$ & $* * *$ & $\begin{array}{l}0.3017 \\
(0.000)\end{array}$ & $* * *$ & $\begin{array}{l}0.3030 \\
(0.000)\end{array}$ & $* * *$ & $\begin{array}{l}0.3279 \\
(0.000)\end{array}$ & $* * *$ & $\begin{array}{l}0.1503 \\
(0.004)\end{array}$ & $* * *$ & $\begin{array}{l}0.1821 \\
(0.000)\end{array}$ & $* * *$ & $\begin{array}{l}1.4569 \\
(0.000)\end{array}$ & $* * *$ & $\begin{array}{l}1.5192 \\
(0.000)\end{array}$ & $* * *$ & $\begin{array}{l}1.2652 \\
(0.000)\end{array}$ & $* * *$ \\
\hline$A G_{i t}$ & $\begin{array}{l}0.1623 \\
(0.000)\end{array}$ & $* * *$ & $\begin{array}{l}0.1275 \\
(0.000)\end{array}$ & $* * *$ & $\begin{array}{l}0.1396 \\
(0.000)\end{array}$ & $* * *$ & $\begin{array}{l}0.1569 \\
(0.000)\end{array}$ & $* * *$ & $\begin{array}{l}0.0851 \\
(0.000)\end{array}$ & $* * *$ & $\begin{array}{l}0.1141 \\
(0.000)\end{array}$ & $* * *$ & $\begin{array}{l}0.1817 \\
(0.000)\end{array}$ & $* * *$ & $\begin{array}{l}0.3306 \\
(0.000)\end{array}$ & $* * *$ & $\begin{array}{l}0.2559 \\
(0.000)\end{array}$ & $* * *$ \\
\hline$G D P_{t}$ & $\begin{array}{l}0.0294 \\
(0.000)\end{array}$ & $* * *$ & $\begin{array}{l}0.0490 \\
(0.000)\end{array}$ & $* * *$ & $\begin{array}{l}0.0349 \\
(0.000)\end{array}$ & *** & $\begin{array}{l}0.0401 \\
(0.000)\end{array}$ & $* * *$ & $\begin{array}{l}0.0552 \\
(0.000)\end{array}$ & *** & $\begin{array}{l}0.0441 \\
(0.000)\end{array}$ & $* * *$ & $\begin{array}{l}0.0230 \\
(0.000)\end{array}$ & *** & $\begin{array}{l}0.0484 \\
(0.000)\end{array}$ & $* * *$ & $\begin{array}{l}0.0300 \\
(0.000)\end{array}$ & $* * *$ \\
\hline$D_{t}$ & $\begin{array}{l}0.0477 \\
(0.029) \\
\end{array}$ & ** & $\begin{array}{l}0.1190 \\
(0.002) \\
\end{array}$ & $* * *$ & $\begin{array}{l}0.0595 \\
(0.22) \\
\end{array}$ & ** & . & & . & & . & & $\begin{array}{l}0.1506 \\
(0.000) \\
\end{array}$ & $* * *$ & $\begin{array}{l}0.3381 \\
(0.000) \\
\end{array}$ & $* * *$ & $\begin{array}{l}0.2057 \\
(0.000) \\
\end{array}$ & $* * *$ \\
\hline $\mathrm{N}$ & 92,211 & & 92,211 & & 92,211 & & 50,616 & & 50,616 & & 50,616 & & 41,595 & & 41,595 & & 41,595 & \\
\hline Adj. $R^{2}$ & 0.5910 & & 0.6027 & & 0.6607 & & 0.5680 & & 0.6270 & & 0.6700 & & 0.5355 & & 0.5524 & & 0.6107 & \\
\hline F-Statistics & 412.7071 & $* * *$ & 396.0887 & $* * *$ & 443.3122 & $* * *$ & 286.0765 & $* * *$ & 281.9683 & $* * *$ & 292.6894 & $* * *$ & 302.9366 & $* * *$ & 338.4044 & $* * *$ & 351.7181 & $* * *$ \\
\hline
\end{tabular}

With respect to the findings of (Armstrong et al. 2010) we next test the influence of the legal system. Breaking down the sample in common and code law groups and analyzing the six columns on the right-hand side of Table 10 , we find again positive coefficients for enforcement in both groups and $R^{2}$ values ranging between $57 \%$ and $67 \%$. The control variables again show the expected signs. The sample split now reveals a highly significant positive coefficient for mandatory disclosure in the common law group, while there are negative coefficients for the code law countries' sample. This is in line with the results of (Armstrong et al. 2010) and seems to indicate a dependence on the legal system. But the results have to be interpreted with caution. Within the groups, there is still substantial heterogeneity in terms of the distribution of observations. Findings could be dominated by the huge capital markets of the U.S. with 39,038 firm year observations and Japan with a number of 29,267 respectively. Furthermore, the group results contradict in parts the positive results on disclosure regulation in the code law country Germany (Meser et al. 2015). According to our model, we point out the proportion of good and bad news firms within a country as the deciding factor for varying country-specific effects, not the legal system. We therefore split the sample further down to the country level. 
Table 4 shows regression results at the country level for the common law group. A very differentiated picture emerges. Our regressions for the U.S. in the columns 1 to 3 provide evidence for a positive relationship between both components of capital market regulation and equity valuation in line with most of the empirical studies. With one exception, the coefficients for disclosure and enforcement are significantly positive at a level of $1 \%$. Our model is able to explain between $56 \%$ and $67 \%$ of variation in the valuation measures. For the UK, our model is able to explain $61 \%$ and $71 \%$ of the variation in the valuation measurement variables. Except for the asset growth rate, all control variables show the expected signs and are in most cases highly significant. However, there is only one significant positive coefficient for disclosure and one significant negative coefficient for enforcement. All other coefficients for disclosure and enforcement are insignificant. We explain this result by the unusual variance in UK's regulatory environment: The UK is the country least affected by regulatory changes. For instance, the enforcement score increases only by 0.10 over the whole sample period of 20 years. This makes it difficult to find significant results for the UK, but also highlights the need for analyses at the country level. The last three columns report the results for Canada, which are again in the expected range. For Canada our model yields an adjusted $\mathrm{R}^{2}$ value between $65 \%$ and $72 \%$. The coefficients for enforcement are positive and significant at a level of $1 \%$. For disclosure we find one of three coefficients with a significantly positive sign at a level of $5 \%$. Except for $R O A_{i t}$ and $A G_{i t}$ all control variables have predicted signs and are mostly significant.

\section{Table 4: Regression Results for Securities Market Regulation - Common Law Countries}

This table reports coefficients and $t$ values in parentheses of two-tailed tests (with significances at the $10 \%, 5 \%$ and $1 \%$ levels indicated by $*, * *$ and $* * *)$ of the following panel ordinary least square (OLS) regressions with firm fixed effects and robust standard errors clustered by firm:

$$
V A L_{i t}=\beta_{0}+\beta_{1} D I S C_{t}+\beta_{2} E N F O+\beta_{3} L N \_S I Z E_{i t}+\beta_{4} L E V_{i t}+\beta_{5} R O A_{i t}+\beta_{6} A G_{i t}+\beta_{7} G D P_{t}+\beta_{7} D_{t}+\eta
$$

Please refer to Table 2 for variable definitions. $L N$ corresponds to the natural logarithm. Intercepts remain unreported for the sake of brevity.

\begin{tabular}{|c|c|c|c|c|c|c|c|c|c|}
\hline & \multicolumn{3}{|c|}{ UNITED STATES } & \multicolumn{3}{|c|}{ UNITED KINGDOM } & \multicolumn{3}{|c|}{ CANADA } \\
\hline & $L N_{-} T O B I N_{i t}$ & $L N \_M T B_{i t}$ & $V A L . F A C_{i t}$ & $L N_{-} T O B I N_{i t}$ & $L N_{-} M T B_{i t}$ & $V A L . F A C_{i t}$ & $L N_{-} T O B I N_{i t}$ & $L N \_M T B_{i t}$ & $V A L . F A C_{i t}$ \\
\hline$\overline{D I S C_{t}}$ & $\begin{array}{l}0.7992 * * * \\
(0.000)\end{array}$ & $\begin{array}{l}1.9473 * * * \\
(0.000)\end{array}$ & $\begin{array}{l}1.2195 * * * \\
(0.000)\end{array}$ & $\begin{array}{l}0.3725 * \\
(0.085)\end{array}$ & $\begin{array}{r}-0.1845 \\
(0.601)\end{array}$ & $\begin{array}{l}0.2558 \\
(0.289)\end{array}$ & $\begin{array}{l}1.8922 * * \\
(0.013)\end{array}$ & $\begin{array}{r}-1.4018 \\
(0.225)\end{array}$ & $\begin{array}{r}0.9953 \\
(0.203)\end{array}$ \\
\hline$E N F O_{t}$ & $\begin{array}{l}0.6119 * * * \\
(0.000)\end{array}$ & $\begin{array}{r}0.0977 \\
(0.232)\end{array}$ & $\begin{array}{l}0.2876 * * * \\
(0.000)\end{array}$ & $\begin{array}{r}-0.0618 \\
(0.651)\end{array}$ & $\begin{array}{r}-0.0819 \\
(0.656)\end{array}$ & $\begin{array}{l}-0.2823 * * \\
(0.048)\end{array}$ & $\begin{array}{l}1.3944 * * * \\
(0.000)\end{array}$ & $\begin{array}{l}2.3132 * * * \\
(0.000)\end{array}$ & $\begin{array}{l}1.5823 * * * \\
(0.000)\end{array}$ \\
\hline$L N \_S I Z E_{i t}$ & $\begin{array}{l}-0.0934 * * * \\
(0.000)\end{array}$ & $\begin{array}{l}0.0957 * * * \\
(0.000)\end{array}$ & $\begin{array}{r}-0.0169 \\
(0.210)\end{array}$ & $\begin{array}{l}-0.1119 * * * \\
(0.000)\end{array}$ & $\begin{array}{r}0.0657 \\
(0.108)\end{array}$ & $\begin{array}{r}-0.0340 \\
(0.257)\end{array}$ & $\begin{array}{l}-0.3481 * * * \\
(0.000)\end{array}$ & $\begin{array}{l}-0.1128 * * * \\
(0.007)\end{array}$ & $\begin{array}{l}-0.2420 * * * \\
(0.000)\end{array}$ \\
\hline$L E V_{i t}$ & $\begin{array}{r}0.0584 \\
(0.117)\end{array}$ & $\begin{array}{l}0.8568 * * * \\
(0.000)\end{array}$ & $\begin{array}{l}0.4148 * * * \\
(0.000)\end{array}$ & $\begin{array}{l}0.4277 * * * \\
(0.000)\end{array}$ & $\begin{array}{l}1.8865 * * * \\
(0.000)\end{array}$ & $\begin{array}{l}1.1814 * * * \\
(0.000)\end{array}$ & $\begin{array}{l}0.1314 \\
(0.404)\end{array}$ & $\begin{array}{l}0.8333 * * * \\
(0.000)\end{array}$ & $\begin{array}{l}0.5427 * * * \\
(0.000)\end{array}$ \\
\hline$R O A_{i t}$ & $\begin{array}{l}0.4265 * * * \\
(0.000)\end{array}$ & $\begin{array}{l}0.1541 * * * \\
(0.009)\end{array}$ & $\begin{array}{l}0.2218 * * * \\
(0.000)\end{array}$ & $\begin{array}{l}1.6393 * * * \\
(0.000)\end{array}$ & $\begin{array}{l}2.3469 * * * \\
(0.000)\end{array}$ & $\begin{array}{l}1.8546 * * * \\
(0.000)\end{array}$ & $\begin{array}{l}-0.3582 * * * \\
(0.000)\end{array}$ & $\begin{array}{l}-0.3775 * * * \\
(0.000)\end{array}$ & $\begin{array}{l}-0.3929 * * * \\
(0.000)\end{array}$ \\
\hline$A G_{i t}$ & $\begin{array}{l}0.2026 * * * \\
(0.000)\end{array}$ & $\begin{array}{l}0.1503 * * * \\
(0.000)\end{array}$ & $\begin{array}{l}0.1745 * * * \\
(0.000)\end{array}$ & $\begin{array}{r}-0.0284 \\
(0.325)\end{array}$ & $\begin{array}{l}-0.1147 * * * \\
(0.007)\end{array}$ & $\begin{array}{l}-0.0845 * * * \\
(0.006)\end{array}$ & $\begin{array}{l}0.0506 * * * \\
(0.003)\end{array}$ & $\begin{array}{l}-0.0481 * * * \\
(0.010)\end{array}$ & $\begin{array}{r}-0.0033 \\
(0.816)\end{array}$ \\
\hline$G D P_{t}$ & $\begin{array}{l}0.0373 * * * \\
(0.000)\end{array}$ & $\begin{array}{l}0.0478 * * * \\
(0.000)\end{array}$ & $\begin{array}{l}0.0400 * * * \\
(0.000)\end{array}$ & $\begin{array}{l}0.0329 * * * \\
(0.000)\end{array}$ & $\begin{array}{l}0.0633 * * * \\
(0.000)\end{array}$ & $\begin{array}{l}0.0413 * * * \\
(0.000)\end{array}$ & $\begin{array}{l}0.0413 * * * \\
(0.000)\end{array}$ & $\begin{array}{l}0.0788 * * * \\
(0.000)\end{array}$ & $\begin{array}{l}0.0486 * * * \\
(0.000)\end{array}$ \\
\hline$D_{t}$ & . & . & . & . & . & . & . & . & . \\
\hline $\begin{array}{l}\mathrm{N} \\
\text { Adj. } \mathrm{R}^{2} \\
\text { F-Statistics }\end{array}$ & $\begin{array}{c}39,038 \\
0.5583 \\
250.7158 * * *\end{array}$ & $\begin{array}{c}39,038 \\
0.6334 \\
223.4521 \text { *** }\end{array}$ & $\begin{array}{r}39,038 \\
0.6718 \\
241.7375 * * *\end{array}$ & $\begin{array}{c}7,231 \\
0.6127 \\
47.1834 * * *\end{array}$ & $\begin{array}{c}7,231 \\
0.6654 \\
74.6587 * * *\end{array}$ & $\begin{array}{c}7,231 \\
0.7144 \\
64.6293 * * *\end{array}$ & $\begin{array}{c}4,347 \\
0.6488 \\
41.7990 * * *\end{array}$ & $\begin{array}{c}4,347 \\
0.6317 \\
44.7969 * * *\end{array}$ & $\begin{array}{c}4,347 \\
0.7174 \\
41.4748 * * *\end{array}$ \\
\hline
\end{tabular}

Table 5 reports the results for the group of the code law countries. The three columns on the left show the results for Japan. The adjusted $\mathrm{R}^{2}$ accounts for between $56 \%$ and $65 \%$ of the overall variation. All coefficients of control variables have the expected signs, and only one is insignificant. All three measurement variables show significant negative coefficients for disclosure and significant positive ones at a level of $1 \%$ for enforcement. This indicates that a higher level of enforcement leads to positive capital market effects in Japan, while a higher level of mandatory disclosure regulation implies lower valuations. In the columns 4 to 6 , we present results for Germany. The adjusted $\mathrm{R}^{2}$ ranges between $52 \%$ and $63 \%$. Except for $R O A_{i t}$, controls show expected signs and significance. The results for Germany document a situation similar to the U.S. and Canada in line with (Meser et al. 2015). The results show highly significant positive associations between the components of capital market regulation and the three valuation measurement variables. Higher levels of disclosure and enforcement leads to higher firm values. For France in the columns 7 to 9, we can present similar results to Japan. Our valuation regressions exhibit an adjusted $\mathrm{R}^{2}$ between $48 \%$ and $58 \%$. Controls are mostly significant and show the predicted signs. We find a significant negative relationship between disclosure regulation and the measurement variable Tobin's Q. The other variables are negative, but not significant to a level of $10 \%$. For enforcement regulation, we find a highly significant positive coefficient for Tobin's Q and a significant negative coefficient for the market-to-book ratio at the level of $10 \%$. Factor analysis reveals a significant positive effect. 
Table 5: Regression Results for Securities Market Regulation - Code Law Countries

This table reports coefficients and $t$ values in parentheses of two-tailed tests (with significances at the $10 \%, 5 \%$ and $1 \%$ levels indicated by $* * *$ and $* * *)$ of the following panel ordinary least square (OLS) regressions with firm fixed effects and robust standard errors clustered by firm:

$$
V A L_{i t}=\beta_{0}+\beta_{1} D I S C_{t}+\beta_{2} E N F O+\beta_{3} L N \_S I Z E_{i t}+\beta_{4} L E V_{i t}+\beta_{5} R O A_{i t}+\beta_{6} A G_{i t}+\beta_{7} G D P_{t}+\beta_{7} D_{t}+\eta
$$

Please refer to Table 2 for variable definitions. $L N$ corresponds to the natural logarithm. Intercepts remain unreported for the sake of brevity.

\begin{tabular}{|c|c|c|c|c|c|c|c|c|c|}
\hline & \multicolumn{3}{|c|}{ JAPAN } & \multicolumn{3}{|c|}{ GERMANY } & \multicolumn{3}{|c|}{ FRANCE } \\
\hline & $L N_{-} T O B I N_{i t}$ & $L N \_M T B_{i t}$ & $V A L . F A C_{i t}$ & $L N \_T O B I N_{i t}$ & $L N \_M T B_{i t}$ & VAL.FAC $C_{i t}$ & $L N \_T O B I N_{i t}$ & $L N \_M T B_{i t}$ & $V A L . F A C_{i t}$ \\
\hline$\overline{D I S C_{t}}$ & $\begin{array}{l}-1.7331 * * * \\
(0.000)\end{array}$ & $\begin{array}{l}-2.7053 * * * \\
(0.000)\end{array}$ & $\begin{array}{l}-1.8974 * * * \\
(0.000)\end{array}$ & $\begin{array}{l}0.7116 * * * \\
(0.000)\end{array}$ & $\begin{array}{l}1.7158 * * * \\
(0.000)\end{array}$ & $\begin{array}{l}0.9274 * * * \\
(0.000)\end{array}$ & $\begin{array}{l}-1.8173 \text { *** } \\
(0.001)\end{array}$ & $\begin{array}{r}-0.4775 \\
(0.712)\end{array}$ & $\begin{array}{r}-1.0119 \\
(0.174)\end{array}$ \\
\hline$E N F O_{t}$ & $\begin{array}{l}1.1595 * * * \\
(0.000)\end{array}$ & $\begin{array}{l}1.9499 * * * \\
(0.000)\end{array}$ & $\begin{array}{l}1.3318 * * * \\
(0.000)\end{array}$ & $\begin{array}{l}0.2318 * * * \\
(0.001)\end{array}$ & $\begin{array}{l}1.6515 * * * \\
(0.000)\end{array}$ & $\begin{array}{l}0.7892 * * * \\
(0.000)\end{array}$ & $\begin{array}{l}2.2707 * * * \\
(0.000)\end{array}$ & $\begin{array}{l}-1.2909 * \\
(0.057)\end{array}$ & $\begin{array}{l}0.6685 * \\
(0.087)\end{array}$ \\
\hline$L N \_S I Z E_{i t}$ & $\begin{array}{l}-0.1119 * * * \\
(0.000)\end{array}$ & $\begin{array}{r}-0.0421 \\
(0.169)\end{array}$ & $\begin{array}{l}-0.0841 * * * \\
(0.000)\end{array}$ & $\begin{array}{l}-0.1071 * * * \\
(0.000)\end{array}$ & $\begin{array}{l}0.1179 * * \\
(0.042)\end{array}$ & $\begin{array}{r}-0.0430 \\
(0.281)\end{array}$ & $\begin{array}{r}-0.0490 \\
(0.213)\end{array}$ & $\begin{array}{l}0.1806 * * \\
(0.015)\end{array}$ & $\begin{array}{r}0.0504 \\
(0.340)\end{array}$ \\
\hline$L E V_{i t}$ & $\begin{array}{l}0.4487 * * * \\
(0.005)\end{array}$ & $\begin{array}{l}1.2990 * * * \\
(0.003)\end{array}$ & $\begin{array}{l}0.8168 * * * \\
(0.004)\end{array}$ & $\begin{array}{l}0.2373 * * * \\
(0.002)\end{array}$ & $\begin{array}{l}0.8080 * * * \\
(0.000)\end{array}$ & $\begin{array}{l}0.5413 * * * \\
(0.000)\end{array}$ & $\begin{array}{l}0.3872 * * * \\
(0.005)\end{array}$ & $\begin{array}{l}1.1384 * * * \\
(0.000)\end{array}$ & $\begin{array}{l}0.7196 * * * \\
(0.001)\end{array}$ \\
\hline$R O A_{i t}$ & $\begin{array}{l}2.3740 * * * \\
(0.000)\end{array}$ & $\begin{array}{l}5.6612 * * * \\
(0.000)\end{array}$ & $\begin{array}{l}3.4558 * * * \\
(0.000)\end{array}$ & $\begin{array}{l}0.7181 * * * \\
(0.000)\end{array}$ & $\begin{array}{c}-0.3771 * \\
(0.060)\end{array}$ & $\begin{array}{l}0.1441 \\
(0.336)\end{array}$ & $\begin{array}{l}2.1554 * * * \\
(0.000)\end{array}$ & $\begin{array}{l}1.2456 * * * \\
(0.003)\end{array}$ & $\begin{array}{l}1.5898 * * * \\
(0.000)\end{array}$ \\
\hline$A G_{i t}$ & $\begin{array}{l}0.1017 * * * \\
(0.002)\end{array}$ & $\begin{array}{l}0.5461 * * * \\
(0.000)\end{array}$ & $\begin{array}{l}0.2262 * * * \\
(0.000)\end{array}$ & $\begin{array}{l}0.2405 * * * \\
(0.000)\end{array}$ & $\begin{array}{l}0.3479 * * * \\
(0.000)\end{array}$ & $\begin{array}{l}0.3199 * * * \\
(0.000)\end{array}$ & $\begin{array}{l}0.1764 * * * \\
(0.000)\end{array}$ & $\begin{array}{r}0.0579 \\
(0.428)\end{array}$ & $\begin{array}{l}0.1441 * * * \\
(0.003)\end{array}$ \\
\hline$G D P_{t}$ & $\begin{array}{l}0.0274 * * * \\
(0.000)\end{array}$ & $\begin{array}{l}0.0460 \text { *** } \\
(0.000)\end{array}$ & $\begin{array}{l}0.0317 * * * \\
(0.000)\end{array}$ & $\begin{array}{l}0.0103 * * * \\
(0.000)\end{array}$ & $\begin{array}{l}0.0733 * * * \\
(0.000)\end{array}$ & $\begin{array}{l}0.0319 \text { *** } \\
(0.000)\end{array}$ & $\begin{array}{l}0.0337 * * * \\
(0.000)\end{array}$ & $\begin{array}{l}0.1070 * * * \\
(0.000)\end{array}$ & $\begin{array}{l}0.0579 * * * \\
(0.000)\end{array}$ \\
\hline$D_{t}$ & . & . & . & $\begin{array}{l}-0.1992 * * * \\
(0.000)\end{array}$ & $\begin{array}{l}-0.5718 * * * \\
(0.000)\end{array}$ & $\begin{array}{l}-0.3091 * * * \\
(0.000)\end{array}$ & $\begin{array}{l}0.0452 \\
(0.595)\end{array}$ & $\begin{array}{r}0.2073 \\
(0.276)\end{array}$ & $\begin{array}{l}0.0805 \\
(0.455)\end{array}$ \\
\hline$\overline{\mathrm{N}}$ & 29,267 & 29,267 & 29,267 & 6,786 & 6,786 & 6,786 & 5,542 & 5,542 & 5,542 \\
\hline Adj. $R^{2}$ & 0.5605 & 0.5798 & 0.6486 & 0.5241 & 0.5946 & 0.6258 & 0.4814 & 0.5547 & 0.5849 \\
\hline F-Statistics & $796.1170 * * *$ & $647.8243 * * *$ & $722.7353 * * *$ & $37.8498 * * *$ & $86.5257 * * *$ & $57.2808 * * *$ & $54.4023 * * *$ & $47.1712 * * *$ & $46.7686 * * *$ \\
\hline
\end{tabular}

Our results suggest that there are country-specific variations between mandatory disclosure regulation and equity valuation. We also document that it is not the legal system which is crucial in explaining differences. Country-specific characteristics have to be taken into account. For Canada, Germany and the U.S., the results indicate that a higher level of mandatory disclosure leads in total to a higher firm value. In France and Japan, the negative effects from the discovery of bad news outweigh the positive ones as predicted in section 4 . The overall economic picture sees these two countries plagued by persistent structural problems. At the firm level, these problems were hidden in the balance sheets and were then gradually exposed when disclosure requirements increased. Examples such as Vivendi in France or Kanebo, Olympus and Toshiba in Japan are not only cases of individual problems but also indicate to some extent structural deficits in these countries. Consequently, investors use better disclosures to update their expected future cash flows and risk expectations.

While we provide evidence that mandatory disclosure can lead to negative capital market effects due to the reveal of bad news, the findings do not indicate that regulatory changes in Japan or France failed in strengthening the capital markets. For one, the positive effects from enforcement changes need to be taken into account. And expecting a consistently positive valuation effect from disclosure would be misplaced optimism. There are not always good news from additional mandatory disclosure regulation in the short run, but in the long run strengthening the information environment will always be good news for disclosure and for the investors that depend on them.

\section{Conclusion}

Information and reporting risks give rise to risk premiums demanded by equity investors. Extended disclosure requirements and stronger enforcement mechanisms address these risks, and capital markets have witnessed ever stricter regulation by means of new disclosure requirements or enforcement institutions. Still, there is empirical evidence of unfavorable outcomes from additional mandatory disclosure regulation. Based on a comprehensive model for disclosure, enforcement and equity valuation, we can show that enforcement regulation will lead to a higher firm value, but stricter disclosure requirements do not. More disclosure regulation reduces information risk, but may give rise to new concerns about the firm's activities and its reporting risk due to the reveal of bad news. The overall effect of increased disclosures may lead to a downwards revision of equity valuation. We point out that it is not the legal system which is crucial. Depending on the proportion of firms that immediately disclose good and bad news on a voluntarily basis to firms that withhold bad news within a country, we expect varying country-specific capital market effects. Our model is thus also able to explain negative consequences of welldesigned regulatory actions.

Using a cross-country dataset of 92,211 firm-year-observations, we provide empirical evidence on the effects 
of regulatory changes. We analyze the regulatory framework of six countries (Canada, France, Germany, Japan, the United Kingdom and the U.S.) between 1991 and 2010 and test for the long-run association between disclosure, enforcement and equity valuation. We examine valuation effects by Tobin's Q, the market-to-book ratio and a valuation factor. Consistent with our model, we find positive associations between our enforcement score value and our valuation measurement variables for all settings: a pooled regression, a split between legal system groups of common and code law countries and for each country separately. The effects of disclosure regulation offer spurious results in the pooled regressions and in the legal system split. Instead, specific country characteristics seem to determine the effects of mandatory disclosure regulation. In Canada, Germany and the U.S., the countries typically examined for effects of disclosure regulations, a higher level of disclosures is associated with a higher firm value. However, we find a negative association for France and Japan. We posit the predominance of firms that have to discover previously withheld bad news in these economies, because they are plagued by long-running macroeconomic problems. For the UK, we are not able to find significant results. We reason this by the small overall change in the regulatory environment for the period under investigation.

Our paper faces some limitations that can be addressed in future studies. The extension to additional countries is obvious. A broadening of the sample could indicate whether the results hold beyond the six largest equity markets. A possible shortcoming is our focus on the country level, which obscures firm level effects. Investigating additional voluntary disclosure on firm level is another possible extension. Matching at the country level or splitting samples by firm characteristics may lead to further insights about the valuation effects of disclosure and enforcement regulation. Especially investigating into the links of accounting choices at firm level and structural difficulties of an economy will demonstrate how these individual decisions take an effect on a market. This could be done by associating accounting quality measures with the performance of industries or countries. Moreover, we do not know a lot about costs. There is a need for future research regarding how to quantify regulatory costs and to which extent they may cause adverse capital market effects respectively. Such an estimation needs to comprise several perspectives as, for instance, administrative costs, compliance and litigation at firm level and, finally, technical obstacles created for accountants, auditors, investors and market makers.

\section{Appendix \\ Leximetric analysis of mandatory disclosure and enforcement score values in the six country cases U.S.}

The U.S. have been the forerunner in virtually any aspect of securities regulation over the last decades. Cornerstone of this development is the strong federal Securities and Exchange Commission (SEC) as set out in the Securities Act (SA-US) of 1933 and in the Securities Exchange Act (SEA) of 1934. Most of their legal provisions relevant for this study remained unchanged until the millennium. They require a high degree of prospectus, insider and interim disclosure levels, and also grant the SEC with an independent mandate to investigate into dissemination of possibly false information or abusive market behavior and to sanction participants with delisting, adverse publicity or charging managers in criminal cases (Ruder et al. 2005). Additionally, the SEC is empowered to issue detailed rules and regulations, as e.g. concerning the disclosure or content in financial reports. Five relevant changes came gradually in force until 2000: the SEC's power to impose administrative fines on listed firms (since 1991: (Morris 1993)), the individual disclosure of directors' remuneration (since 1993: (Terrion 1993)) first auditor independence requirements (since 1998: (Brown et al. 2000)), improved segment reporting (since 1998: (Roberts 2008)) and the introduction of material information disclosure requirements (since 2000: (Bailey et al. 2003)). These provisions were topped with the enactment of the Sarbanes-Oxley Act (SOX) in the aftermath of the Enron and WorldCom scandals. Management commentary disclosures, and (again) auditor independence requirements were tightened, a pro-active enforcement of accounting rules and sworn statements were introduced in 2003 (Paredes 2003). Many of these provisions were transposed to other national regulations and set the benchmark until today. Table A1 illustrates the values for each year throughout the observation period for the U.S. and provides explanations for score value changes. 
Table A1: Score Values by Year, U.S.

This table shows the yearly disclosure and enforcement regulation score values and provide explanations for the changes in the U.S. for the period between 1991 and 2010.

\begin{tabular}{|c|c|c|c|c|c|c|c|c|c|c|}
\hline & 1991 & 1992 & 1993 & 1994 & 1995 & 1996 & 1997 & 1998 & 1999 & 2000 \\
\hline D1: Information Accounting & $1^{\mathrm{a}}$ & 1 & 1 & 1 & 1 & 1 & 1 & 1 & 1 & 1 \\
\hline D2: Mgmt. Commentary & 0.75 & 0.75 & 0.75 & 0.75 & 0.75 & 0.75 & 0.75 & 0.75 & 0.75 & 0.75 \\
\hline D3: Material Information & 0 & 0 & 0 & 0 & 0 & 0 & 0 & 0 & 0 & $1^{\mathrm{c}}$ \\
\hline D4: Quarterly Reports & $1^{\mathrm{d}}$ & 1 & 1 & 1 & 1 & 1 & 1 & 1 & 1 & 1 \\
\hline D5: Segment Information & 0.5 & 0.5 & 0.5 & 0.5 & 0.5 & 0.5 & 0.5 & $1^{\mathrm{e}}$ & 1 & 1 \\
\hline D6: Compensation & 0.5 & 0.5 & $1^{\mathrm{f}}$ & 1 & 1 & 1 & 1 & 1 & 1 & 1 \\
\hline D7: Inside Ownership & $1^{\mathrm{g}}$ & 1 & 1 & 1 & 1 & 1 & 1 & 1 & 1 & 1 \\
\hline D8: Prospectus & $1^{\mathrm{h}}$ & 1 & 1 & 1 & 1 & 1 & 1 & 1 & 1 & 1 \\
\hline D9: Shareholders & $1^{\mathrm{i}}$ & 1 & 1 & 1 & 1 & 1 & 1 & 1 & 1 & 1 \\
\hline D10: Transactions & $1^{\mathrm{j}}$ & 1 & 1 & 1 & 1 & 1 & 1 & 1 & 1 & 1 \\
\hline \multirow[t]{2}{*}{ Disclosure Score } & 0.78 & 0.78 & 0.83 & 0.83 & 0.83 & 0.83 & 0.83 & 0.88 & 0.88 & 0.98 \\
\hline & 2001 & 2002 & 2003 & 2004 & 2005 & 2006 & 2007 & 2008 & 2009 & 2010 \\
\hline D1: Information Accounting & 1 & 1 & 1 & 1 & 1 & 1 & 1 & 1 & 1 & 1 \\
\hline D2: Mgmt. Commentary & 0.75 & 0.75 & $1^{\mathrm{b}}$ & 1 & 1 & 1 & 1 & 1 & 1 & 1 \\
\hline D3: Material Information & 1 & 1 & 1 & 1 & 1 & 1 & 1 & 1 & 1 & 1 \\
\hline D4: Quarterly Reports & 1 & 1 & 1 & 1 & 1 & 1 & 1 & 1 & 1 & 1 \\
\hline D5: Segment Information & 1 & 1 & 1 & 1 & 1 & 1 & 1 & 1 & 1 & 1 \\
\hline D6: Compensation & 1 & 1 & 1 & 1 & 1 & 1 & 1 & 1 & 1 & 1 \\
\hline D7: Inside Ownership & 1 & 1 & 1 & 1 & 1 & 1 & 1 & 1 & 1 & 1 \\
\hline D8: Prosp & 1 & 1 & 1 & 1 & 1 & 1 & 1 & 1 & 1 & 1 \\
\hline D9: Shareholders & 1 & 1 & 1 & 1 & 1 & 1 & 1 & 1 & 1 & 1 \\
\hline D10: Transactions & 1 & 1 & 1 & 1 & 1 & 1 & 1 & 1 & 1 & 1 \\
\hline \multirow[t]{2}{*}{ Disclosure Score } & 0.98 & 0.98 & 1.00 & 1.00 & 1.00 & 1.00 & 1.00 & 1.00 & 1.00 & 1.00 \\
\hline & 1991 & 1992 & 1993 & 1994 & 1995 & 1996 & 1997 & 1998 & 1999 & 2000 \\
\hline E1: Appo & $1^{\mathrm{k}}$ & 1 & 1 & 1 & 1 & 1 & 1 & 1 & 1 & 1 \\
\hline E2: Auditor Independence & 0 & 0 & 0 & 0 & 0 & 0 & 0 & $0.5^{1}$ & 0.5 & 0.5 \\
\hline E3: Focus & $1^{\mathrm{m}}$ & 1 & 1 & 1 & 1 & 1 & 1 & 1 & 1 & 1 \\
\hline E4: Rule-making power & $1^{\mathrm{n}}$ & 1 & 1 & 1 & 1 & 1 & 1 & 1 & 1 & 1 \\
\hline E5: Tenure & $0^{\circ}$ & 0 & 0 & 0 & 0 & 0 & 0 & 0 & 0 & 0 \\
\hline E6: Document & $1^{\mathrm{p}}$ & 1 & 1 & 1 & 1 & 1 & 1 & 1 & 1 & 1 \\
\hline E7: Review & 0.5 & 0.5 & 0.5 & 0.5 & 0.5 & 0.5 & 0.5 & 0.5 & 0.5 & 0.5 \\
\hline E8: Sanctions Company & $1^{\mathrm{r}}$ & 1 & 1 & 1 & 1 & 1 & 1 & 1 & 1 & 1 \\
\hline E9: Sanctions Management & $0.5^{\mathrm{s}}$ & 0.5 & 0.5 & 0.5 & 0.5 & 0.5 & 0.5 & 0.5 & 0.5 & 0.5 \\
\hline E10: Sworn Statement & 0 & 0 & 0 & 0 & 0 & 0 & 0 & 0 & 0 & 0 \\
\hline Enforcement Score & 0.60 & 0.60 & 0.60 & 0.60 & 0.60 & 0.60 & 0.60 & 0.65 & 0.65 & 0.65 \\
\hline
\end{tabular}

Table A1, continued on next page 
Table A1, continued

\begin{tabular}{lrrrrrrrrrr}
\hline & 2001 & 2002 & 2003 & 2004 & 2005 & 2006 & 2007 & 2008 & 2009 & 2010 \\
\hline E1: Appointment & 1 & 1 & 1 & 1 & 1 & 1 & 1 & 1 & 1 & 1 \\
E2: Auditor Independence & 0.5 & 0.5 & $1^{1}$ & 1 & 1 & 1 & 1 & 1 & 1 & 1 \\
E3: Focus & 1 & 1 & 1 & 1 & 1 & 1 & 1 & 1 & 1 & 1 \\
E4: Rule-making power & 1 & 1 & 1 & 1 & 1 & 1 & 1 & 1 & 1 & 1 \\
E5: Tenure & 0 & 0 & 0 & 0 & 0 & 0 & 0 & 0 & 0 & 0 \\
E6: Document & 1 & 1 & 1 & 1 & 1 & 1 & 1 & 1 & 1 & 1 \\
E7: Review & 0.5 & 0.5 & $1^{\mathrm{q}}$ & 1 & 1 & 1 & 1 & 1 & 1 & 1 \\
E8: Sanctions Company & 1 & 1 & 1 & 1 & 1 & 1 & 1 & 1 & 1 & 1 \\
E9: Sanctions Management & 0.5 & 0.5 & 0.5 & 0.5 & 0.5 & 0.5 & 0.5 & 0.5 & 0.5 & 0.5 \\
E10: Sworn Statement & 0 & 0 & $1^{\mathrm{t}}$ & 1 & 1 & 1 & 1 & 1 & 1 & 1 \\
\hline Enforcement Score & 0.65 & 0.65 & 0.85 & 0.85 & 0.85 & 0.85 & 0.85 & 0.85 & 0.85 & 0.85 \\
\hline
\end{tabular}

a Rooting on the decision usefulness paradigm set out in the provisions of the conceptual framework (SFAC 1.9), the statements issued by the FASB are regarded as information accounting for the entire sample period ((Ball et al. 2000), p. 3).

b Since 1980, management commentary (termed Management Discussion and Analysis, MD\&A) is mandatory in filings to the U.S. Securities and Exchange Commission (SEC; (Schroeder \& Gibson 1990), p. 78). The Sarbanes-Oxley Act (SOX) amended the requirements in 2003 under the Securities Exchange Act of 1934 (SEA) by e.g. the disclosure of off-balance sheet items (SOX s. 401 (a)(j); SEA, 2002, s. 13 (j)), as well as Regulation S-K by including a statement on the effectiveness of internal control systems ((Paredes 2003), p. 425).

c The Regulation Fair Disclosure (Reg FD) came into force in 2000 and requires since then an immediate information of any material change ((Bailey et al. 2003), p. 2487). For this purpose, filings on Form 8$\mathrm{K}$ are to be made ((Lerman \& Livnat 2010), p. 753).

d Provisions of the SEA require a continuous quarterly financial reporting on Form 10-Q (SEA s. 13 (a)(2))

e Up to 1998, segment reporting followed the risks-and-return approach which allowed substantial discretion on what and how to report ((Roberts 2008), pp. 436). Since 1998, the revised accounting rules SFAS 131 are based on the management approach.

f Until 1992 Regulation S-K required listed firms to disclose the individual compensation of the five highest paid officers (if remuneration exceeded a threshold) and the compensation of the directors as a group ((Pierce 1981), p. 135). This was amended by 1993 when the individual remuneration to top executives had to be continuously reported ((Terrion 1993), pp. 1175).

$\mathrm{g}$ Ownership of related parties is to be reported. In this respect, no material amendments were made to SEA s. 16 (a)(1) during the observation period.

$\mathrm{h} \quad$ The general requirement to disclose a prospectus is prescribed in an unchanged way in the U.S. Securities Act of 1933 (SA-US) s. 10 (a)(1).

i A direct or indirect owning of $10 \%$ or more is to be reported. In this respect, no material amendments were made to SEA s. 12 (b)(1D), SEA s. 16 (a)(1) during the observation period.

j Directors' dealings must be disclosed. In this respect, no material amendments were made to SEA s. 16 (a)(2) during the observation period.

k As an independent regulatory authority, the members of the SEC are appointed by the President of the U.S. in consent with the Senate (SEA s. 4 (a)).

$1 \quad$ Since 1998, auditors are liable if dependent ((Brown et al. 2000), p. 445 et seq.; Rule 102(e)). This weak provision is replaced by the Sarbanes-Oxley Act, and since then auditors have to state their independence (SOX s. 201; SEA s. 10A (g)).

$\mathrm{m} \quad$ Supervision of banks has been carried out by separate federal institutions during the observation period. Currently, at the federal level the following institutions are competent: the Federal Reserve System, the Federal Deposit Insurance Corporation and the Office of the Comptroller of the Currency.

Table A1, continued on next page 
Table A1, concluded

The SEC is granted rule-making powers in by various provisions in the Acts of 1933 and 1934 (e.g., SEA s. 13(a), SEA s. 14(a)(1), SEA s. 15(d), SA-US s. 19(a)). Throughout the sample period, the number of applicable regulations rules increased and i.a. regulates accounting and disclosure (to name the most prominent ones: Regulations S-K, S-X). Courts or other authorities may not amend or repeal these rules.

- Members of the SEC "can be removed from office by the President only for good cause" during the entire observation period ((Peters 1988), p. 286). Because of this, we rate variable E5=0. It is in contrary to (La Porta et al. 2006)) and their element Appointment, which is conceptual similar.

$\mathrm{p} \quad$ The Commission can seize any relevant document (SEA s. 21 (b)).

q Until 2003, the SEC filings were used to reactively enforce financial reports. In the cause of SarbanesOxley Act, a pro-active review and enforcement of accounting rules was introduced (SOX, 2003, s. 408).

$\mathrm{r} \quad$ Legal penalties for listed firms include the restatement of false registration statements and stop orders (SEA s. 8(b)\&(d)), temporary suspensions from trade or registration (SEA s. 12(k)(1A)\&(j)) and adverse publicity (SEA s. 15 (c)(4)). These provisions remained qualitatively unchanged during the sample period. Material changes were introduced after 1990 with the Remedies Act, empowering the SEC to impose administrative fines not only for insiders but also for listed firms ((Morris 1993), p. 157; SEA s. 21B(a)).

s Management can be brought to court, or sanctioned with fines or imprisonment if the person was aware of committing an offense (SEA s. 21(d)(3); SEA s. 32(a)). Apart from the maximum penalties, these provisions remained unchanged throughout the sample period.

$t \quad$ A certification of financial reports by directors is compulsory since the enactment of the SarbanesOxley Act ((Ruder et al. 2005), p. 1138; SOX s. 302(a)).

\section{Japan}

Although Japan has one of the largest equity and debt markets in the world, and substantial parts of its Securities Exchange Law (SEL) were transposed from the U.S. after the Second World War, its securities market regulation intensity falls behind the other countries in almost every year during our observation period. Three reasons come into play: The financing via large blockholders and banks (Markham 2002); an administration which for a long time tried to protect insiders in order to the conserve structures and foster growth of domestic companies (Pardieck 2001); and lastly a regulatory system based on consensual solutions instead of litigation and enforcement (Small 2003). This approach was also reflected in the institutional setting: initially, a department within the Ministry of Finance (MOF) was competent for market oversight, but with limited powers (Lu 1993). The Japanese banking crisis in the early 1990s changed the perspective on financial markets: bank recapitalization, supervision and securities regulation were transferred - in the so-called "Japanese Big Bang" - from the MOF to a unique and separate institution, the Financial Services Agency (FSA-JP) in 1998 ((Hoshi \& Ito 2004); (Markham 2002)). In the beginning (1998), the Supervisor was named Financial Supervisory Agency, and was not responsible for bank recapitalization. The shift to today's name and competences happened in 2000. Under its umbrella, the Securities Exchange and Surveillance Commission (SESC) is specially designated for enforcement. Despite these institutional rearrangements, the FSA-JP and SESC have remained not truly independent and are lacking rulemaking power. Apart from early changes (1989-1992) in the major and insider ownership disclosure as well as in establishing a reactive review of accounting rules, the only increase in relevant regulation happened after the millennium: the requirement of quarterly reporting and independent auditors came into force (both in 2004), and the so called "J-SOX" was enacted in 2008 (Wisenbaker 2010). It transferred the most fundamental of the U.S. provisions to Japanese law, like increased management commentary disclosures and sworn statements. Even considering these recent changes, Japan can be characterized as having a "low regulation" framework. Table A2 shows and explains changes for Japan. 
Table A2: Score Values by Year, Japan

This table shows the yearly disclosure and enforcement regulation score values and provide explanations for the changes in Japan for the period between 1991 and 2010.

\begin{tabular}{|c|c|c|c|c|c|c|c|c|c|c|}
\hline & 1991 & 1992 & 1993 & 1994 & 1995 & 1996 & 1997 & 1998 & 1999 & 2000 \\
\hline D1: Information Accounting & 0 & 0 & 0 & 0 & 0 & 0 & 0 & 0 & 0 & 0 \\
\hline D2: Mgmt. Commentary & 0.5 & 0.5 & 0.5 & 0.5 & 0.5 & 0.5 & 0.5 & 0.5 & 0.5 & 0.5 \\
\hline D3: Material Information & $1^{\mathrm{c}}$ & 1 & 1 & 1 & 1 & 1 & 1 & 1 & 1 & 1 \\
\hline D4: Quarterly Reports & 0.5 & 0.5 & 0.5 & 0.5 & 0.5 & 0.5 & 0.5 & 0.5 & 0.5 & 0.5 \\
\hline D5: Segment Information & 0.5 & 0.5 & 0.5 & 0.5 & 0.5 & 0.5 & 0.5 & 0.5 & 0.5 & 0.5 \\
\hline D6: Compensation & 0.5 & 0.5 & 0.5 & 0.5 & 0.5 & 0.5 & 0.5 & 0.5 & 0.5 & 0.5 \\
\hline D7: Inside Ownership & 0 & 0 & 0 & 0 & 0 & 0 & 0 & 0 & 0 & 0 \\
\hline D8: Prospectus & $1^{\mathrm{h}}$ & 1 & 1 & 1 & 1 & 1 & 1 & 1 & 1 & 1 \\
\hline D9: Shareholders & $1^{\mathrm{i}}$ & 1 & 1 & 1 & 1 & 1 & 1 & 1 & 1 & 1 \\
\hline D10: Transactions & $1^{\mathrm{j}}$ & 1 & 1 & 1 & 1 & 1 & 1 & 1 & 1 & 1 \\
\hline \multirow[t]{2}{*}{ Disclosure Score } & 0.60 & 0.60 & 0.60 & 0.60 & 0.60 & 0.60 & 0.60 & 0.60 & 0.60 & 0.60 \\
\hline & 2001 & 2002 & 2003 & 2004 & 2005 & 2006 & 2007 & 2008 & 2009 & 2010 \\
\hline D1: Information Accounting & 0 & 0 & 0 & 0 & 0 & 0 & 0 & 0 & 0 & $0.5^{\mathrm{a}}$ \\
\hline D2: Mgmt. Commentary & 0.5 & 0.5 & 0.5 & 0.5 & 0.5 & 0.5 & 0.5 & $0.75^{\mathrm{b}}$ & 0.75 & 0.75 \\
\hline D3: Material Information & 1 & 1 & 1 & 1 & 1 & 1 & 1 & 1 & 1 & 1 \\
\hline D4: Quarterly Reports & 0.5 & 0.5 & 0.5 & $1^{\mathrm{d}}$ & 1 & 1 & 1 & 1 & 1 & 1 \\
\hline D5: Segment Information & 0.5 & 0.5 & 0.5 & 0.5 & 0.5 & 0.5 & 0.5 & $1^{\mathrm{e}}$ & 1 & 1 \\
\hline D6: Compensation & 0.5 & 0.5 & 0.5 & 0.5 & 0.5 & 0.5 & 0.5 & 0.5 & 0.5 & $1^{\mathrm{f}}$ \\
\hline D7: Inside Ownership & 0 & 0 & 0 & 0 & 0 & 0 & $1^{g}$ & 1 & 1 & 1 \\
\hline D8: Prospectus & 1 & 1 & 1 & 1 & 1 & 1 & 1 & 1 & 1 & 1 \\
\hline D9: Shareholders & 1 & 1 & 1 & 1 & 1 & 1 & 1 & 1 & 1 & 1 \\
\hline D10: Transactions & 1 & 1 & 1 & 1 & 1 & 1 & 1 & 1 & 1 & 1 \\
\hline \multirow[t]{2}{*}{ Disclosure Score } & 0.60 & 0.60 & 0.60 & 0.65 & 0.65 & 0.65 & 0.75 & 0.83 & 0.83 & 0.93 \\
\hline & 1991 & 1992 & 1993 & 1994 & 1995 & 1996 & 1997 & 1998 & 1999 & 2000 \\
\hline E1: Appointment & $0^{\mathrm{k}}$ & 0 & 0 & 0 & 0 & 0 & 0 & 0 & 0 & 0 \\
\hline E2: Auditor Independence & 0 & 0 & 0 & 0 & 0 & 0 & 0 & 0 & 0 & 0 \\
\hline E3: Focus & $0^{\mathrm{m}}$ & 0 & 0 & 0 & 0 & 0 & 0 & 0 & 0 & 0 \\
\hline E4: Rule-making power & 0.5 & 0.5 & 0.5 & 0.5 & 0.5 & 0.5 & 0.5 & $0^{\mathrm{n}}$ & 0 & 0 \\
\hline E5: Tenure & $0^{\circ}$ & 0 & 0 & 0 & 0 & 0 & 0 & 0 & 0 & 0 \\
\hline E6: Document & $1^{\mathrm{p}}$ & 1 & 1 & 1 & 1 & 1 & 1 & 1 & 1 & 1 \\
\hline E7: Review & 0 & 0.5 & 0.5 & 0.5 & 0.5 & 0.5 & 0.5 & 0.5 & 0.5 & 0.5 \\
\hline E8: Sanctions Company & 0 & 0 & 0 & 0 & 0 & 0 & 0 & 0 & 0 & 0 \\
\hline E9: Sanctions Management & $0.5^{\mathrm{s}}$ & 0.5 & 0.5 & 0.5 & 0.5 & 0.5 & 0.5 & 0.5 & 0.5 & 0.5 \\
\hline E10: Sworn Statement & 0 & 0 & 0 & 0 & 0 & 0 & 0 & 0 & 0 & 0 \\
\hline Enforcement Score & 0.20 & 0.25 & 0.25 & 0.25 & 0.25 & 0.25 & 0.25 & 0.20 & 0.20 & 0.20 \\
\hline
\end{tabular}

Table A2, continued on next page 
Table B2, continued

\begin{tabular}{lrrrrrrrrrr}
\hline & 2001 & 2002 & 2003 & 2004 & 2005 & 2006 & 2007 & 2008 & 2009 & 2010 \\
\hline E1: Appointment & 0 & 0 & 0 & 0 & 0 & 0 & 0 & 0 & 0 & 0 \\
E2: Auditor Independence & 0 & 0 & 0 & $0.5^{1}$ & 0.5 & 0.5 & 0.5 & 0.5 & 0.5 & 0.5 \\
E3: Focus & 0 & 0 & 0 & 0 & 0 & 0 & 0 & 0 & 0 & 0 \\
E4: Rule-making power & 0 & 0 & 0 & 0 & 0 & 0 & 0 & 0 & 0 & 0 \\
E5: Tenure & 0 & 0 & 0 & 0 & 0 & 0 & 0 & 0 & 0 & 0 \\
E6: Document & 1 & 1 & 1 & 1 & 1 & 1 & 1 & 1 & 1 & 1 \\
E7: Review & 0.5 & 0.5 & 0.5 & 0.5 & $1^{\mathrm{q}}$ & 1 & 1 & 1 & 1 & 1 \\
E8: Sanctions Company & 0 & 0 & 0 & 0 & $1^{\mathrm{r}}$ & 1 & 1 & 1 & 1 & 1 \\
E9: Sanctions Management & 0.5 & 0.5 & 0.5 & 0.5 & 0.5 & 0.5 & 0.5 & 0.5 & 0.5 & 0.5 \\
E10: Sworn Statement & 0 & 0 & 0 & 0 & 0 & 0 & 0 & $1^{\mathrm{t}}$ & 1 & 1 \\
\hline Enforcement Score & 0.20 & 0.20 & 0.20 & 0.25 & 0.40 & 0.40 & 0.40 & 0.50 & 0.50 & 0.50 \\
\hline
\end{tabular}

a Japanese law requires different accounting rules for single and group accounts. Both rule sets were nor regarded as furnishing decision-useful information. Apart for a few exempted firms, all had to follow Japanese GAAP until 2009. Since 2010, “designated IFRS" that have been endorsed by the Financial Services Agency of Japan (FSA-JP) may be voluntarily applied to group accounts.

b Business reports are part of the filing documents before and throughout the entirely observation period ((Heftel 1983), p. 156). In the course of implementing the "J-SOX" - amendments to the securities law tailored after the U.S. SOX -, internal control reports became mandatory from 2008 onwards (current rule: Art. 24-4-4 (1)\&(4) of the Financial Instruments and Exchange Act (FIEA) of 2015). Consequently, D2 is now rated at 0.75 .

c Material information always had to be released to investors ((Tatsuta 1978), p. 104), though the number of relevant events was considerably expanded (e.g., in 1989: (Lu 1993), p. 127); current rule: FIEA, 2015, Art. 166.

d Half-yearly reporting was mandatory for listed firms until 2003 ((Itami \& Itoh 1982), p. 8). From 2004 onwards, the Tokyo Stock Exchange listing rules require quarterly reports ((Kubota et al. 2010), p. 2), and in 2008 this provision became statutory (current rule: FIEA, 2015, Art. 24-4-7).

e Until 1993, only the types of segments with its revenues had to be disclosed. After that date, further items were added in the course of time by the Ministry of Finance (MOF) rulings and the Japanese Institute of CPAs (JICPA) that always based on the risks-and-return approach ((Ozu \& Gray 2001), p. 2). Since 2008, Standard 17 of the Accounting Standards Board of Japan (ASBJ) requires the management approach, with we translate to a full disclosure.

f Traditionally, directors' remuneration had only to be disclosed on an aggregate level ((Iwasaki et al. 2012), p. 9). In 2010, this regulation was changed so that the pay to each director earning more than JPY 100,000 must be disclosed ((Mizuno 2010), p. 660). This amendment fulfils the requirement of this variable concerning the individual disclosure of the pay to top management.

g Inside ownership per se did not require a disclosure, only sales and purchases ((Akashi 1989), p. 1301). For that reason, we rate variable D7 $=0$. This provision was changed for 2007 and onwards when the ASBJ Standard 11 came into force which requires the disclosure of any holding.

$\mathrm{h} \quad$ A prospectus is required for all offerings on regulated markets ((Misawa 1974), p. 11; FIEA, 2015, Art. 13(1)).

i At the beginning of our observation period in 1991, the MOF had to be notified about any shareholding above $5 \%$. This document has to be made available to any investor for a time span of five years. Currently, the Enforcement Institution is in charge to disclose these filings ((Hirose 1991), p. 508); FIEA, 2015, Art. 27-23(1) \& 27-28(1)).

$\mathrm{j} \quad$ In the course of the 1989 amendments to the Securities Exchange Law (SEL), transactions of directors and principal owners had to be reported to the MOF and disclosed by the firm ((Akashi 1989), p. 1303; (Ramseyer 2011), p. 6). Since 2007, also ASBJ Standard 11 requires the disclosure of any transaction above $10 \%$ shareholdings. 

((Markham 2002), p. 63). In 1998, the FSA-JP (at first Financial Supervisory Agency, since 2000 Financial Services Agency) was founded as the Enforcement Institution, and under its umbrella the SESC remained responsible for enforcement. Even though the SESC is formally independent from the FSA-JP, it is not competent to process substantial cases (e.g., issuing the order to pay an administrative penalty) which has to be delegated to the FSA-JP ((Small 2003), p. 339). For that reason, we assumed the FSA-JP as the Enforcement Institution. Its Commissioner is appointed by the Prime Minister, but the FSA-JP does not dispose of a board ((Bebenroth et al. 2009), p. 188). For these reasons, we set E1 $=0$ throughout the complete time period.

1 Weak provisions were in force regarding auditor independence before 2004. In that year, it was introduced that auditors may not perform non-audit services - which increases E2 to 0.5. Auditors must not be dependent, but a certificate of independence is not necessary (current rules: Art. $24 \& 34-11$ of the CPA Act (CPAA) of 2008).

$\mathrm{m} \quad$ Banking and securities supervision has been never separated in Japan: At first both was carried out by the MOF through its Securities and Banking Bureaus ((Bebenroth et al. 2009), p. 184), and afterwards by the FSA-JP ((Hoshi \& Ito 2004), p. 230).

$\mathrm{n} \quad$ At the time the MOF was the competent Enforcement Institution, it was able to issue ordinances with respect to financial market regulation (( $\mathrm{Lu} \mathrm{1993),} \mathrm{p.} \mathrm{152).} \mathrm{The} \mathrm{FSA-JP} \mathrm{so} \mathrm{far} \mathrm{only} \mathrm{promulgated}$ supervision policies (i.e., organizational procedures) and guidelines in English. Hence we assigned E4 $=0.5$ until 1997 and $\mathrm{E} 4=0$ afterwards.

- The Securities Bureau was a department of the MOF and its heads did not enjoy an independent tenure. The FSA-JP Commissioner can be dismissed at the Prime Minister's will ((IMF 2003), p. 44).

p The MOF was empowered to require the production of any document ((Misawa 1974), pp. 11). The SESC assumed this right, and may - by an administrative order or with a court warrant - demand the production of documents from any person involved ((Lu 1993), p. 147; (SESC 1994); current rule: FIEA, 2015, Art. 211).

q Between 1992 and 2004, the Enforcement Institution was empowered to sanction any false information in filings (SESC 1994). This reactive approach was replaced in the following year by a pro-active inspection of disclosure documents ((SESC 2008), pp. 16); current rule: FIEA, 2015, Art. 26).

$\mathrm{r} \quad$ Before 2005, the Enforcement Institution only had investigative powers ((Markham 2002), s. 388; (Mackey et al. 2005), s. 383). Since then, administrative fines, monetary penalties or the restatement of documents can be ordered (current rules: FIEA, 2015, Art. 10, 24-2, 172-2).

s Management can be sanctioned with fines or imprisonment if the person was aware of committing an offense ((Ramsay 1992), s. 261; current rules: FIEA, 2015, Art. 175, 178, 197)

$\mathrm{t}$ Part of the J-SOX amendments to the securities law, a provision was introduced that the directors have to certify the registration documents in 2008 ((Wisenbaker 2010), p. 495); current rule: FIEA, 2015, Art. 24-4-2 (1)).

\section{United Kingdom}

From an institutional perspective, regulation history falls into two phases. The first lasted until 1996 when the Department of Trade and Industry (DTI) and various Self-Regulating Organizations (SROs) like the London Stock Exchange (LSE) shared the capital market oversight. In the literature, this period is usually characterized as an intransparent regime with few statutory rules (Pimlott 1985). While mostly true for brokers/dealers over the entire period, changes happened for listed firms already in 1984. The enactment of the Companies Act (1985), implementing European directives on company law, and amendments to the LSE Listing Rules brought about a steep incline in disclosure and also in enforcement (Lorenz 1987). Even though the 1986 "Big Bang" in the UK meant a new Financial Services Act and a framework of stronger SRO regulation, it did not directly affect accountancy and equity issuers ((Hablutzel 1992); (High \& Shah 1993)). Only in 1989/1990, major steps were taken with the set up of a reactive enforcement of accounting rules by the Financial Reporting Review Panel (FRRP), and disclosure rules were strengthened (Fearnley \& Hines 2003). The second phase started in 1997 with gradually delegating powers to the Financial Services Authority (FSA-UK). The competences to oversee the capital market was gradually transferred to the Securities and Investment Board (SIB) starting in 1997 which was renamed FSA-UK later. Full statutory powers were only granted with the enactment of the Financial Services and Markets Act (FSMA) which came into force in 2001. It is a separated enforcement agency and assumed competences e.g. from the LSE with broad rule-making (Listing Rules, Disclosure and Transparency Rules), investigative and sanctioning powers (against firms and managers). The FRRP is still competent for most accounting rule enforcement, and also gained pro-active powers in 2005. In general, the UK can be termed as a 
"high regulation" regime. The changes in disclosure and enforcement values are reported in Table A3.

Table A3: Score Values by Year, United Kingdom

This table shows the yearly disclosure and enforcement regulation score values and provide explanations for the changes in UK for the period between 1991 and 2010.

\begin{tabular}{|c|c|c|c|c|c|c|c|c|c|c|}
\hline & 1991 & 1992 & 1993 & 1994 & 1995 & 1996 & 1997 & 1998 & 1999 & 2000 \\
\hline D1: Information Accounting & $1^{\mathrm{a}}$ & 1 & 1 & 1 & 1 & 1 & 1 & 1 & 1 & 1 \\
\hline D2: Mgmt. Commentary & 0 & 0 & 0 & 0 & 0 & 0 & 0 & 0 & 0 & 0 \\
\hline D3: Material Information & $1^{\mathrm{c}}$ & 1 & 1 & 1 & 1 & 1 & 1 & 1 & 1 & 1 \\
\hline D4: Quarterly Reports & $0.5^{\mathrm{d}}$ & 0.5 & 0.5 & 0.5 & 0.5 & 0.5 & 0.5 & 0.5 & 0.5 & 0.5 \\
\hline D5: Segment Information & 0.5 & 0.5 & 0.5 & 0.5 & 0.5 & 0.5 & 0.5 & 0.5 & 0.5 & 0.5 \\
\hline D6: Compensation & 0.5 & 0.5 & 0.5 & 0.5 & 0.5 & 0.5 & 0.5 & 0.5 & 0.5 & 0.5 \\
\hline D7: Inside Ownership & $1^{\mathrm{g}}$ & 1 & 1 & 1 & 1 & 1 & 1 & 1 & 1 & 1 \\
\hline D8: Prospectus & $1^{\mathrm{h}}$ & 1 & 1 & 1 & 1 & 1 & 1 & 1 & 1 & 1 \\
\hline D9: Shareholders & $1^{\mathrm{i}}$ & 1 & 1 & 1 & 1 & 1 & 1 & 1 & 1 & 1 \\
\hline D10: Transactions & $1^{\mathrm{j}}$ & 1 & 1 & 1 & 1 & 1 & 1 & 1 & 1 & 1 \\
\hline \multirow[t]{2}{*}{ Disclosure Score } & 0.75 & 0.75 & 0.75 & 0.75 & 0.75 & 0.75 & 0.75 & 0.75 & 0.75 & 0.75 \\
\hline & 2001 & 2002 & 2003 & 2004 & 2005 & 2006 & 2007 & 2008 & 2009 & 2010 \\
\hline D1: Information Accounting & 1 & 1 & 1 & 1 & 1 & 1 & 1 & 1 & 1 & 1 \\
\hline D2: Mgmt. Commentary & 0 & 0 & 0 & 0 & 0 & 0 & $0.5^{\mathrm{b}}$ & $0,75^{\mathrm{b}}$ & $1^{\mathrm{b}}$ & 1 \\
\hline D3: Material Information & 1 & 1 & 1 & 1 & 1 & 1 & 1 & 1 & 1 & 1 \\
\hline D4: Quarterly Reports & 0.5 & 0.5 & 0.5 & 0.5 & 0.5 & 0.5 & 0.5 & 0.5 & 0.5 & 0.5 \\
\hline D5: Segment Information & 0.5 & 0.5 & 0.5 & 0.5 & 0.5 & 0.5 & 0.5 & 0.5 & $1^{\mathrm{e}}$ & 1 \\
\hline D6: Compensation & 0.5 & $1^{\mathrm{f}}$ & 1 & 1 & 1 & 1 & 1 & 1 & 1 & 1 \\
\hline D7: Inside Ownership & 1 & 1 & 1 & 1 & 1 & 1 & 1 & 1 & 1 & 1 \\
\hline D8: Prospectus & 1 & 1 & 1 & 1 & 1 & 1 & 1 & 1 & 1 & 1 \\
\hline D9: Shareholders & 1 & 1 & 1 & 1 & 1 & 1 & 1 & 1 & 1 & 1 \\
\hline D10: Transactions & 1 & 1 & 1 & 1 & 1 & 1 & 1 & 1 & 1 & 1 \\
\hline \multirow[t]{2}{*}{ Disclosure Score } & 0.75 & 0.80 & 0.80 & 0.80 & 0.80 & 0.80 & 0.85 & 0.88 & 0.95 & 0.95 \\
\hline & 1991 & 1992 & 1993 & 1994 & 1995 & 1996 & 1997 & 1998 & 1999 & 2000 \\
\hline E1: Appointment & $0^{\mathrm{k}}$ & 0 & 0 & 0 & 0 & 0 & 0 & 0 & 0 & 0 \\
\hline E2: Auditor Independence & $0.5^{1}$ & 0.5 & 0.5 & 0.5 & 0.5 & 0.5 & 0.5 & 0.5 & 0.5 & 0.5 \\
\hline E3: Focus & 1 & 1 & 1 & 1 & 1 & 1 & $0^{\mathrm{m}}$ & 0 & 0 & 0 \\
\hline E4: Rule-making power & 0.5 & 0.5 & 0.5 & 0.5 & 0.5 & 0.5 & 0.5 & 0.5 & 0.5 & 0.5 \\
\hline E5: Tenure & $0^{\circ}$ & 0 & 0 & 0 & 0 & 0 & 0 & 0 & 0 & 0 \\
\hline E6: Document & $1^{\mathrm{p}}$ & 1 & 1 & 1 & 1 & 1 & 1 & 1 & 1 & 1 \\
\hline E7: Review & 0.5 & 0.5 & 0.5 & 0.5 & 0.5 & 0.5 & 0.5 & 0.5 & 0.5 & 0.5 \\
\hline E8: Sanctions Company & 0.5 & 0.5 & 0.5 & 0.5 & 0.5 & 0.5 & 0.5 & 0.5 & 0.5 & 0.5 \\
\hline E9: Sanctions Management & $0.5^{\mathrm{s}}$ & 0.5 & 0.5 & 0.5 & 0.5 & 0.5 & 0.5 & 0.5 & 0.5 & 0.5 \\
\hline E10: Sworn Statement & $1^{\mathrm{t}}$ & 1 & 1 & 1 & 1 & 1 & 1 & 1 & 1 & 1 \\
\hline Enforcement Score & 0.55 & 0.55 & 0.55 & 0.55 & 0.55 & 0.55 & 0.45 & 0.45 & 0.45 & 0.45 \\
\hline
\end{tabular}

Table A3, continued on next page 
Table B3, continued

\begin{tabular}{lrrrrrrrrrr}
\hline & 2001 & 2002 & 2003 & 2004 & 2005 & 2006 & 2007 & 2008 & 2009 & 2010 \\
\hline E1: Appointment & 0 & 0 & 0 & 0 & 0 & 0 & 0 & 0 & 0 & 0 \\
E2: Auditor Independence & 0.5 & 0.5 & 0.5 & 0.5 & 0.5 & 1 & 1 & 1 & 1 & 1 \\
E3: Focus & 0 & 0 & 0 & 0 & 0 & 0 & 0 & 0 & 0 & 0 \\
E4: Rule-making power & $1^{\mathrm{n}}$ & 1 & 1 & 1 & 1 & 1 & 1 & 1 & 1 & 1 \\
E5: Tenure & 0 & 0 & 0 & 0 & 0 & 0 & 0 & 0 & 0 & 0 \\
E6: Document & 1 & 1 & 1 & 1 & 1 & 1 & 1 & 1 & 1 & 1 \\
E7: Review & 0.5 & 0.5 & 0.5 & 0.5 & 1 & 1 & 1 & 1 & 1 & 1 \\
E8: Sanctions Company & $1^{\mathrm{r}}$ & 1 & 1 & 1 & 1 & 1 & 1 & 1 & 1 & 1 \\
E9: Sanctions Management & 0.5 & 0.5 & 0.5 & 0.5 & 0.5 & 0.5 & 0.5 & 0.5 & 0.5 & 0.5 \\
E10: Sworn Statement & 1 & 1 & 1 & 1 & 1 & 1 & 1 & 1 & 1 & 1 \\
\hline Enforcement Score & 0.55 & 0.55 & 0.55 & 0.55 & 0.60 & 0.65 & 0.65 & 0.65 & 0.65 & 0.65 \\
\hline
\end{tabular}

a Throughout the entire observation period, accounting rules and practice were rooted in the "true and fair view" principle (already in s. 123 \& Sched. 8 s. 23 (2) of the Companies Act (CA) of 1948). As opposed to other true-and-fair-view provisions in European code law countries, the literature acknowledges the UK case as being in line with the common law tradition of investor information ((Ball et al. 2000), p. 4; (Cunningham 2002), p. 897). From 2005 onwards, listed firms have to follow IFRS.

b Submitting a management commentary (termed Operating \& Financial Review, OFR) was not mandatory for many years. Initially, the CA (1985) (Operating and Financial Review and Directors' Report etc.) Regulations aimed at introducing an OFR, but the provision was repealed in the same year. Since 2007, the CA (2006) s. 417 stipulates a Business Review, in 2008 s. 410A was inserted into this act to require the reporting about off-balance sheet arrangements, and since 2009, the Large and Medium-sized Companies and Groups (Accounts and Reports) Regulations (2008) s. 11 \& Sched. 8 s. 6 stipulate the disclosure of risk management statements.

c Material change in the business of a listed firm had to be announced via the Company Announcements Office (CAO) operated by the London Stock Exchange (LSE; (Frost \& Pownall 1994), p. 78). The information dissemination was transferred to the Regulatory Information Service, but the general disclosure requirement remained unchanged (ss. 9.1 \& 9.2 of the LSE Listing Rules (LR) of 2002; current unchanged rules: ss. 9.6.1-21 of the Financial Services Authority of the UK (FSA-UK) LR of 2012).

d Semiannual reporting was a listing requirement since 1973 ((Opong 1995), p. 269; LSE LR (2002) s. 12.46), and was transferred to the Disclosure Rules and Transparency Rules (DTR) in 2007 (FSA-UK DTR s. 4.2.2 R).

e Segment reporting became compulsory in 1990, and followed a risks-and-return approach ((Emmanuel \& Garrod 2002), p. 215). With the change to IFRS and the adoption of IFRS 8, which came into effect in 2009 , the management approach was implemented.

f Only the aggregate remuneration to directors had to be disclosed until 2001 (CA, 1948, s. 196; CA, 1985, s. 231 \& Sched. 5 s. 22, from 1990 onwards in Sched. 6 s. 1 (1)). The individual disclosure of executive compensation was introduced in 2002 (at first by adding to the CA (1985) s. 234B \& Sched. 7A s. 6; later by CA (2006) s. 420 (1), and the Large and Medium-sized Companies and Groups (Accounts and Reports) Regulations (2008) s. 11 \& Sched. 8 s. 7).

$\mathrm{g} \quad$ Initially, a list tabulating the directors' shareholdings had to be made accessible at the firm's office and at its general meeting (CA, 1948, s. 195 (7)). After that, insider ownership had to be reported to the firm and to the LSE to release this information (CA, 1985, ss. 324 \& 329). Since 2005, this requirement is part of the DTR (2005) s. 2.8.1 R (as set out in s. 96A (2) of the Financial Services and Markets Act (FSMA) as revised in 2005).

h A firm could apply for an exemption of the prospectus requirement of the LSE (CA, 1948, s. 39 (1)). With the 1985 CA amendments, the European Prospectus Directive was transposed as statutory part of the LSE Listing Regulations ((Pimlott 1985), p. 142). In 2000, this provision was transferred to the FSMA (2000) ss. $84 \& 85$. The exemptions named in e.g. LSE LR (2002) ss. 5.23A-5.30 are only minor in nature. 
Investors owning more than $5 \%$ of the shares have had to issue a report to the company and a disclosure via the CAO (Goergen \& Renneboog 1998), p. 7; CA, 1985, s. 201, 202) since 1985. Later, the LSE LR (2002) s. 12.43 (1), and the DTR (2010) ss. 5.1.2 R \& 5.9.1 R require this or a stronger disclosure.

j Directors' transactions have to be reported to the firm and to the LSE to release this information (CA, 1985, ss. 324 \& 329). Listing Rules also require the disclosure of related parties (e.g., LSE LR (2002) s. 11.1). Since 2005, this requirement is part of the DTR (2005) ss. 3.1.2 R \& 3.1.4 R (as set out in FSMA, 2005, s. 96A (2)), and was codified in 2008 in the Large and Medium-sized Companies and Groups (Accounts and Reports) Regulations (2008) Sched. 3 s. 90.

k Until 1996, the Department of Trade and Industry (DTI) fulfilled the functions of securities market surveillance without operating a separate Enforcement Institution. In parallel, the Securities and Investment Board (SIB) was founded in 1987 with a board appointed by the DTI ((Hablutzel 1992)). It only had competences to supervise Self-Regulating Organizations (SROs) but not listed firms, which is why we do not label it as the Enforcement Institution. Only in 1997, these powers were transferred to the SIB that was renamed FSA of the UK. Its chairman and governing body are appointed by the Treasury (FSMA, 2000, Sched. 1 s. 2 (3)). Consequently, E1 always takes the value of 0.

1 Audit fees have to be disclosed since 1989 (CA, 1989, ss. 390A, 390B; Large and Medium-sized Companies and Groups (Accounts and Reports) Regulations, 2008, s. 5 (1)). Additionally, auditors must be independent (CA, 2006, s. 1214), but do not have to certify their independence.

m A separate banking and securities supervision existed up to 1996. In that time the Bank of England ((Di Noia \& Di Giorgio 1999), p. 366) and the DTI were in charge of these powers, respectively. The FSAUK is an unitary regulator.

n Accounting and other securities market rules were made by the DTI that were subject to parliamentary approval (CA, 1985, s. 256). The power to issue rules and regulations was transferred to the FSA-UK in 2001 (FSMA, 2000, s. 138). Between 2001 and 2010, no other regulatory institution had the power to amend these rules. No other regulator has the power to amend these rules.

o During the time the DTI was in charge of market surveillance, no independent tenure of supervising individuals existed. Under the FSA-UK regime, its chairman and governing board can be removed at the Treasury's will (FSMA, 2000, Sched. 1 s. 2 (3)).

p The DTI was empowered to require the production of any document ((Sikka \& Willmott 1995); CA, 1985, ss. 432, $434 \& 447$ ), and equally is the FSA-UK (FSMA, 2000, ss. 165, 172).

$\mathrm{q}$ A continuous filing requirement exists with the Companies House, a DTI agency, which is not empowered to review the documents ((Fearnley \& Hines 2003)). This power was given to the Financial Reporting Review Panel (FRRP) which was set up in 1990 as a reactive enforcement body. Its competences were increased to a pro-active review by means of the Companies (Audit, Investigations and Community Enterprise) Act, 2004, ss. 10-15.

$r \quad$ Companies could be brought to court or fined by the DTI (CA, 1985, ss. 61 (2) \& 438). The FSA-UK may e.g. resort on adverse publicity, impose financial penalties, suspend the listing, or bring a firm to court ((Fearnley \& Hines 2003); FSMA, 2000, ss. 77, 91, 93 \& 206; CA, 2006, s. 456).

s Managers could be fined or held criminally liable under the DTI regime (CA, 1948, ss. 147 (4), 173 (3) \& 438; CA, 1985, ss. 222 (3) \& 450). Also the FSA-UK may sanction persons by administrative and criminal measures if they acted knowingly (FSMA, 2000, ss. 91, 380 \& 397).

$\mathrm{t}$ Even though the directors had to sign financial reports in the years of this observation period, the Companies Act did not explicitly impose a liability (CA, 1948, s. 169). This was introduced in 1985 and exists since this date (CA, 1985, ss. 238 \& 245; CA, 2006, s. 414).

\section{Germany}

Capital market regulation in Germany used to be weak since German financing patterns traditionally relied on bank loans and large blockholder financing (Ball et al. 2000). Installing a powerful enforcement regime was not in the focus of regulatory initiatives. Only the effort of the European Union to foster high quality financial reporting and converging international capital markets caused a shift in securities market regulation towards investor protection. Since the mid 1990s, Germany made great efforts in enhancing disclosure requirements and enforcement. The adoption of IFRS for consolidated accounts and a most recent initiative with the Accounting Modernization Act (Bilanzrechtsmodernisierungsgesetz, BilMoG) of 2009 constitute major milestones in disclosure rules for German listed companies. Those advances in company disclosure were accompanied by changes in the enforcement structure, finding its peak in the foundation of the first single capital market regulator in Germany, the Federal Financial Supervisory Authority (FFSA; Bundesanstalt für Finanzdienstleistungsaufsicht, BaFin). In corporation with the Financial Reporting Enforcement Panel (FREP; Deutsche Prüfstelle für Rechnungslegung, DPR) which was established in 2004, Germany operates a two-tier control system for capital 
market oversight. Given the remarkable development within the last 15 years, securities market regulation still remains on a low level suggesting that disclosure regulation is not fully geared towards investor orientation compared to highly regulated regimes such as the U.S. Given these circumstances, Germany can be seen by as a "low regulation" model. All changes of disclosure and enforcement changes are shown in Table A4.

Table A4: Score Values by Year, Germany

This table shows the yearly disclosure and enforcement regulation score values and provide explanations for the changes in Germany for the period between 1991 and 2010.

\begin{tabular}{|c|c|c|c|c|c|c|c|c|c|c|}
\hline & 1991 & 1992 & 1993 & 1994 & 1995 & 1996 & 1997 & 1998 & 1999 & 2000 \\
\hline D1: Information Accounting & 0 & 0 & 0 & 0 & 0 & 0 & 0 & 0.5 & 0.5 & 0.5 \\
\hline D2: Mgmt. Commentary & 0.25 & 0.25 & 0.25 & 0.25 & 0.25 & 0.25 & 0.25 & 0.25 & 0.25 & 0.25 \\
\hline D3: Material Information & $1^{\mathrm{c}}$ & 1 & 1 & 1 & 1 & 1 & 1 & 1 & 1 & 1 \\
\hline D4: Quarterly Reports & 0 & 0 & 0 & 0 & 0 & 0 & 0 & 0 & 0 & 0 \\
\hline D5: Segment Information & 0 & 0 & 0 & 0 & 0 & 0 & 0 & $0.5^{\mathrm{e}}$ & 0.5 & 0.5 \\
\hline D6: Compensation & 0.5 & 0.5 & 0.5 & 0.5 & 0.5 & 0.5 & 0.5 & 0.5 & 0.5 & 0.5 \\
\hline D7: Inside Ownership & $0^{\mathrm{g}}$ & 0 & 0 & 0 & 0 & 0 & 0 & 0 & 0 & 0 \\
\hline D8: Prospectus & $0.5^{\mathrm{h}}$ & 0.5 & 0.5 & 0.5 & 0.5 & 0.5 & 0.5 & 0.5 & 0.5 & 0.5 \\
\hline D9: Shareholders & 0 & 0 & 0 & 0 & $0.5^{\mathrm{i}}$ & 0.5 & 0.5 & 0.5 & 0.5 & 0.5 \\
\hline D10: Transactions & 0 & 0 & 0 & 0 & 0 & 0 & 0 & 0 & 0 & 0 \\
\hline \multirow[t]{2}{*}{ Disclosure Score } & 0.23 & 0.23 & 0.23 & 0.23 & 0.28 & 0.28 & 0.28 & 0.38 & 0.38 & 0.38 \\
\hline & 2001 & 2002 & 2003 & 2004 & 2005 & 2006 & 2007 & 2008 & 2009 & 2010 \\
\hline D1: Information Accounting & 0.5 & 0.5 & 0.5 & 0.5 & $1^{\mathrm{a}}$ & 1 & 1 & 1 & 1 & 1 \\
\hline D2: Mgmt. Commentary & 0.25 & 0.25 & 0.25 & 0.25 & 0.5 & 0.5 & 0.5 & 0.5 & $1^{\mathrm{b}}$ & 1 \\
\hline D3: Material Information & 1 & 1 & 1 & 1 & 1 & 1 & 1 & 1 & 1 & 1 \\
\hline D4: Quarterly Reports & 0 & 0 & $1^{\mathrm{d}}$ & 1 & 1 & 1 & 1 & 1 & 1 & 1 \\
\hline D5: Segment Information & 0.5 & 0.5 & 0.5 & 0.5 & $1^{\mathrm{e}}$ & 1 & 1 & 1 & 1 & 1 \\
\hline D6: Compensation & 0.5 & 0.5 & 0.5 & 0.5 & 0.5 & $1^{\mathrm{f}}$ & 1 & 1 & 1 & 1 \\
\hline D7: Inside Ownership & 0 & 0 & 0 & 0 & 0 & 0 & 0 & 0 & 0 & 0 \\
\hline D8: Prospectus & 0.5 & 0.5 & 0.5 & 0.5 & 0.5 & 0.5 & 0.5 & 0.5 & 0.5 & 0.5 \\
\hline D9: Shareholders & 0.5 & 0.5 & 0.5 & 0.5 & 0.5 & 0.5 & $1^{\mathrm{i}}$ & 1 & 1 & 1 \\
\hline D10: Transactions & 0 & $1^{\mathrm{j}}$ & 1 & 1 & 1 & 1 & 1 & 1 & 1 & 1 \\
\hline \multirow[t]{2}{*}{ Disclosure Score } & 0.38 & 0.48 & 0.58 & 0.58 & 0.75 & 0.80 & 0.80 & 0.80 & 0.85 & 0.85 \\
\hline & 1991 & 1992 & 1993 & 1994 & 1995 & 1996 & 1997 & 1998 & 1999 & 2000 \\
\hline E1: Appointment & $0^{\mathrm{k}}$ & 0 & 0 & 0 & 0 & 0 & 0 & 0 & 0 & 0 \\
\hline E2: Auditor Independence & 0.5 & 0.5 & 0.5 & 0.5 & 0.5 & 0.5 & 0.5 & 0.5 & 0.5 & 0.5 \\
\hline E3: Focus & $1^{\mathrm{m}}$ & 1 & 1 & 1 & 1 & 1 & 1 & 1 & 1 & 1 \\
\hline E4: Rule-making power & 0 & 0 & 0 & 0 & $1^{\mathrm{n}}$ & 1 & 1 & 1 & 1 & 1 \\
\hline E5: Tenure & $0^{\circ}$ & 0 & 0 & 0 & 0 & 0 & 0 & 0 & 0 & 0 \\
\hline E6: Document & 0 & 0 & 0 & 0 & $1^{\mathrm{p}}$ & 1 & 1 & 1 & 1 & 1 \\
\hline E7: Review & 0 & 0 & 0 & 0 & $0.5^{\mathrm{q}}$ & 0.5 & 0.5 & 0.5 & 0.5 & 0.5 \\
\hline E8: Sanctions Company & 0 & 0 & 0 & 0 & $0.5^{\mathrm{r}}$ & 0.5 & 0.5 & 0.5 & 0.5 & 0.5 \\
\hline E9: Sanctions Management & $1^{\mathrm{s}}$ & 1 & 1 & 1 & 1 & 1 & 1 & 1 & 1 & 1 \\
\hline E10: Sworn Statement & $0^{t}$ & 0 & 0 & 0 & 0 & 0 & 0 & 0 & 0 & 0 \\
\hline Enforcement Score & 0.25 & 0.25 & 0.25 & 0.25 & 0.55 & 0.55 & 0.55 & 0.55 & 0.55 & 0.55 \\
\hline
\end{tabular}

Table A4, continued on next page 


\begin{tabular}{lrrrrrrrrrr} 
Table A4, continued & 2001 & 2002 & 2003 & 2004 & 2005 & 2006 & 2007 & 2008 & 2009 & 2010 \\
\hline E1: Appointment & 0 & 0 & 0 & 0 & 0 & 0 & 0 & 0 & 0 & 0 \\
E2: Auditor Independence & 0.5 & 0.5 & 0.5 & 0.5 & 0.5 & 0.5 & 0.5 & 0.5 & $1^{1}$ & 1 \\
E3: Focus & 1 & 1 & 1 & 1 & 1 & 1 & 1 & 1 & 1 & 1 \\
E4: Rule-making power & 1 & 1 & 1 & 1 & 1 & 1 & 1 & 1 & 1 & 1 \\
E5: Tenure & 0 & 0 & 0 & 0 & 0 & 0 & 0 & 0 & 0 & 0 \\
E6: Document & 1 & 1 & 1 & 1 & 1 & 1 & 1 & 1 & 1 & 1 \\
E7: Review & 0.5 & 0.5 & 0.5 & 0.5 & 1 & 1 & 1 & 1 & 1 & 1 \\
E8: Sanctions Company & 0.5 & 0.5 & 0.5 & 0.5 & 0.5 & 0.5 & 0.5 & 0.5 & 0.5 & 0.5 \\
E9: Sanctions Management & 1 & 1 & 1 & 1 & 1 & 1 & 1 & 1 & 1 & 1 \\
E10: Sworn Statement & 0 & 0 & 0 & 0 & 0 & 0 & $1^{\text {t }}$ & 1 & 1 & 1 \\
\hline Enforcement Score & 0.55 & 0.55 & 0.55 & 0.55 & 0.60 & 0.60 & 0.70 & 0.70 & 0.75 & 0.75 \\
\hline
\end{tabular}

a Beginning in 1998, listed German companies have been given the option to set up their consolidated financial statement according to IFRS. Starting from fiscal year 2005 and in accordance with $\$ 315 \mathrm{a}$ of the Commercial Code of Germany (CC-DE - Handelsgesetzbuch), listed companies have been obliged to disclose consolidated accounts in accordance with IFRS.

b Firms were required to disclose additional, narrative information on the firm's overall performance. There was no specification on the kind of information to be released in the management commentary. With the enactment of the Financial Statement Guidelines Act (Bilanzrichtlinien-Gesetz) in 1986, this requirement was implemented to CC-DE \$315. In 2005 and with the enactment of the Corporate Reporting Reformation Act (Bilanzrechtsreformgesetz), listed companies had been required to release additional disclosures in the management commentary. Further, the Accounting Modernization Act (Bilanzrechtsmodernisierungsgesetz), which became effective in May 2009, extended the management commentary requirements by enlarging the disclosure rules in CC-DE $\$ 315$ (2).

c Firms have to provide material information starting from May 1987. The legislator introduced §44a to the Stock Exchange Act (Börsengesetz) to foster disclosure of value relevant information. In 1995, it was replaced by $\S 15$ of the Securities Trading Act (STA - Wertpapierhandelsgesetz).

d The Frankfurt Stock Exchange Listing Rules (FSE LR; Börsenordnung) require Prime Standard companies to disclose quarterly reports (FSE LR §51). This provision was set into force in January 2003.The Prime Standard is a segment on Frankfurt Stock Exchange with the highest transparency requirements. Companies of the General Standard are required to publish only quarterly interim reports about their situation (lower information level). However, because of element description, we do not vary the score value over the stock exchange segments.

e With the initiation of the Corporate Sector Supervision and Transparency Act (Gesetz zur Kontrolle und Transparenz im Unternehmensbereich) and the Capital Raising Facilitation Act (Kapitalaufnahmeerleichterungsgesetz) in 1998, listed companies have been required to reveal information on regional and business segments. This requirement was settled in CC-DE §297. With the change to IFRS in 2005 along with IAS 14 listed companies had to publish more information on regional and business segments. With the adoption of IFRS 8 coming into effect in 2009, the management approach was implemented.

f The requirement to report the aggregated compensation of the management board was settled in CCDE $\$ 314$ (1)6 in 1986. Later, the Management Compensation Disclosure Act (VorstandsvergütungsOffenlegungsgesetz) amended the Commercial Code by requiring listed companies to disclose information on the compensation structure of each board member, starting from August 2005. Shareholders have the right to vote against disclosing management compensation for a maximum period of five years (CC-DE $\$ 314$ (2) and CC-DE §286 (5)).

$\mathrm{g}$ There is no law or listing requirement regarding the disclosure of management's ownership stakes (CCDE $\$ 314$ (1) 6 only requires a publicly listed firm to disclose management stakeholdings if they are part of total remuneration). The German Corporate Governance Codex (GCGC - Deutscher Corporate Governance Kodex) recommends firms to publish the proportion of shares that is held by management and the board of directors if it exceeds $1 \%$ of a firm's total shares outstanding. The GCGC is neither a legal statute nor does it represent a part of listing requirements. 
According to $\S 1$ of the Selling Prospectus Act (Verkaufsprospektgesetz) companies that offered shares to the public had to deliver prospectus to potential investors, starting from January 1991. In 2005, this provision was replaced by the Securities Prospectus Act (SPA - Wertpapierprospektgesetz) which pronounces the prospectus requirement in $\S 3$. Controls on the formal correctness of prospectus were only established in 1998 (SPA §8a). These prospectus disclosure requirements have always included various exemptions (SPA §4; SPA §4).

i STA $\$ 21$ (1) and STA $\$ 26$ (1) oblige publicly listed firms to disclose shareholdings if they exceed thresholds of $3,5,10,15,20,25,30,50$ or $75 \%$, starting from 1995 . The rules do not clearly indicate whether the thresholds include indirect ownerships. We therefore allocate a score value of 0.5 to the item. Later, we augment the value to 1 since CC-DE $\$ 315(4) 3$ coming into force in July 2006, states that direct and indirect ownerships have to be disclosed in the management commentary if they exceed $10 \%$.

j Information on share transactions of board members (directors' dealings) or related parties has to be published starting from July 2002. This requirement is settled in STA §15a. The initiation of the Transparency Realization Act (Transparenzrichtlinie-Umsetzungsgesetz), which came into force in January 2007, extended these requirements (i.e., information has to be provided to the official business register).

k In 1995, the Federal Securities Supervisory Office (FSSO - Bundesaufsichtsamt für den Wertpapierhandel) commenced its operations as a financial market supervisory authority. The government used to propose a candidate for the presidency of the FSSO to the Federal President of Germany. The latter then appointed the FSSO president (STA §3(2)). In 2002, the FSSO was displaced by the Federal Financial Supervisory Authority (FFSA - Bundesanstalt für Finanzdienstleistungsaufsicht). Its administrative council consists of 17 members according to the Financial Services Supervisory Act (FSSA - Finanzdienstleistungsaufsichtsgesetz) §7(3), All members are appointed by government branches (FSSA §7 (5)).

1 The Financial Statement Guidelines Act transferred some independence criteria for auditors to the CC$\mathrm{DE} \S 319$ in 1986 . We therefore allocated a score value of 0.5 to the item. Independence criteria were strengthened at a later point in time. In accordance with the Accounting Modernization Act and becoming effective in 2009, auditors have to explicitly confirm their independence in audited financial reports (CC-DE $\S 321(4 a))$.

m The Second Financial Market Promotion Act in 1994 and the associated foundation of the FSSO in 1995 transferred securities market supervision to a federal institution. Banking supervision was carried out by the Federal Banking Supervisory Office (Bundesaufsichtsamt für das Kreditwesen) which had been already founded in 1962. With the formation of the FFSA in 2002, the FSSO, the Federal Banking Supervisory Office and the Federal Insurance Supervisory Office (Bundesaufsichtsamt für das Versicherungswesen) were merged into a one unitary supervision institution. The surveillance of stock exchanges has ever since been conducted by supervision authorities of the federal states, so the variable takes the value 1 over the whole observation period.

n With the enactment of STA §4(1) in 1995, the FSSO was given authority to issue directives that ensure the functioning of the securities market, without prior approval of governmental institutions. This legal power was transferred to the FFSA in 2002 and specified in 2004 (STA §4(2)).

- There was no rule concerning dismissals of agency members when the FSSO had been in charge of securities market surveillance. In fact, during its seven years in operation, there had been only one president. Being the legal rule since 2002, FSSA §7(7) states that dismissals of members of the FFSA's Administrative Council can only be conducted after having heard the appointing institution.

p From 1995 onwards the FSSO has the competences to require documents from a company (STA $\S 16(3) 1)$. From 2005 onwards, the Financial Reporting Enforcement Panel (FREP - Deutsche Prüfstelle für Rechnungslegung) acts as an enforcement instance on voluntary basis (established according to CC-DE $\$ 342 \mathrm{~b}$; STA §37p). Hence, the FREP can only require documents from companies that agree to the examination. If a company refuses, the case will be handed to the FFSA that disposes - since then - of the legal power to order withdrawal of documents from any person of a firm under investigation (STA §4 (3) \& §37o (4)-(5)).

q Since 1995 the FSSO has the competences to reactively review financial reports (FSSO, 1995, s. 29). In 2005, a systematic review of filing documents was established. In this year, the FREP was set up and the FSSA gained the competences to proactively review financial reports (CC-DE $\S 342 \mathrm{~b}$ (2); STA $\S 37 \mathrm{o}(1))$. The separation into a voluntary and compulsory stage as outlined in footnote $p$ also extends to the review. 
$\mathrm{r} \quad$ Along with its foundation in 1995, the FSSO was given the power to impose financial sanctions. Its successor, the FFSA, assumed these competencies. If the FFSA suspects a criminal act, it passes the case to the federal prosecutor (STA $\S 4(5)$ ). In the area of banking supervision, the FFSA can impose further sanctions, like the cancellation of the banking license ( $\$ 33$ of the Bank Credit Act (Kreditwesengesetz)). However, banking supervision is not in the focus of our study. We therefore keep a constant value of 0.5 throughout the time series.

s The disclosure of misleading information has been punished by fine or imprisonment throughout the entire observation period. In 1986 moved to $\$ 264 \mathrm{a}$ of the Criminal Code (see also CC-DE $\$ 334 \&$ $\S 335)$.

$\mathrm{t}$ With the enactment of the Transparency Realization Act in January 2007, board members and directors have been required to affirm the material accuracy of financial statements. The requirement was settled in CC-DE $\$ 264(2)$.

\section{France}

Along with the creation of the French Securities and Exchange Commission (COB - Commission des Opérations de Bourse) in 1967, France was one of the first countries in Europe to establish an influential enforcement body following the example of the SEC. Acting as a stock market regulator, the COB was given authority to set accounting guidance statements and to impose sanctions in case of non-compliance (Brown \& Tarca 2005). In contrast to a powerful enforcement structure, disclosure regulation first played a minor role in capital market regulation; company disclosure in France was rather shaped by tax-related issues than by motives to provide outside investors with useful information ((Giner \& Rees 2001); (La Porta et al. 1997);). Major changes in disclosure have only been promoted during the years between 2001 and 2010, coming along with the overall aim to improve financial reporting quality in the European Union. Those changes are primarily related to the mandatory adoption of IFRS and associated increased disclosure requirements (e.g. in-depth segment reporting and management commentary). Disclosure regulation only caught up to the U.S. after the millennium. The traditionally high enforcement level was further increased in 2003 when the COB and two further enforcement bodies were merged into the Financial Markets Authority (AMF - Autorité des Marchés Financiers). It acts as the single capital market regulator and is endowed with additional power for market interventions. Considering all aspects of disclosure and enforcement, France is a "high regulation" system. Table A5 reports all changes in disclosure and enforcement score values. 
Table A5: Score Values by Year, France

This table shows the yearly disclosure and enforcement regulation score values and provide explanations for the changes in France for the period between 1991 and 2010.

\begin{tabular}{|c|c|c|c|c|c|c|c|c|c|c|}
\hline & 1991 & 1992 & 1993 & 1994 & 1995 & 1996 & 1997 & 1998 & 1999 & 2000 \\
\hline D1: Information Accounting & 0 & 0 & 0 & 0 & 0 & 0 & 0 & 0 & 0 & 0 \\
\hline D2: Mgmt. Commentary & 0.25 & 0.25 & 0.25 & 0.25 & 0.25 & 0.25 & 0.25 & 0.25 & 0.25 & 0.25 \\
\hline D3: Material Information & $1^{\mathrm{c}}$ & 1 & 1 & 1 & 1 & 1 & 1 & 1 & 1 & 1 \\
\hline D4: Quarterly Reports & $0.5^{\mathrm{d}}$ & 0.5 & 0.5 & 0.5 & 0.5 & 0.5 & 0.5 & 0.5 & 0.5 & 0.5 \\
\hline D5: Segment Information & 0.5 & 0.5 & 0.5 & 0.5 & 0.5 & 0.5 & 0.5 & 0.5 & 0.5 & 0.5 \\
\hline D6: Compensation & 0.5 & 0.5 & 0.5 & 0.5 & 0.5 & 0.5 & 0.5 & 0.5 & 0.5 & 0.5 \\
\hline D7: Inside Ownership & $1^{\mathrm{g}}$ & 1 & 1 & 1 & 1 & 1 & 1 & 1 & 1 & 1 \\
\hline D8: Prospectus & $0.5^{\mathrm{h}}$ & 0.5 & 0.5 & 0.5 & 0.5 & 0.5 & 0.5 & 0.5 & 0.5 & 0.5 \\
\hline D9: Shareholders & $1^{\mathrm{i}}$ & 1 & 1 & 1 & 1 & 1 & 1 & 1 & 1 & 1 \\
\hline D10: Transactions & 0 & 0 & 0 & 0 & 0 & 0 & 0 & 0 & 0 & 0 \\
\hline \multirow[t]{2}{*}{ Disclosure Score } & 0.53 & 0.53 & 0.53 & 0.53 & 0.53 & 0.53 & 0.53 & 0.53 & 0.53 & 0.53 \\
\hline & 2001 & 2002 & 2003 & 2004 & 2005 & 2006 & 2007 & 2008 & 2009 & 2010 \\
\hline D1: Information Accounting & 0 & 0 & 0 & 0 & $1^{\mathrm{a}}$ & 1 & 1 & 1 & 1 & 1 \\
\hline D2: Mgmt. Commentary & 0.25 & $0.5^{\mathrm{b}}$ & 0.5 & 0.5 & 0.5 & 0.5 & 0.5 & 0.5 & 0.5 & 0.5 \\
\hline D3: Material Information & 1 & 1 & 1 & 1 & 1 & 1 & 1 & 1 & 1 & 1 \\
\hline D4: Quarterly Reports & 0.5 & 0.5 & 0.5 & 0.5 & 0.5 & 0.5 & 0.5 & 0.5 & 0.5 & 0.5 \\
\hline D5: Segment Information & 0.5 & 0.5 & 0.5 & 0.5 & $1^{\mathrm{e}}$ & 1 & 1 & 1 & 1 & 1 \\
\hline D6: Compensation & $1^{\mathrm{f}}$ & 1 & 1 & 1 & 1 & 1 & 1 & 1 & 1 & 1 \\
\hline D7: Inside Ownership & 1 & 1 & 1 & 1 & 1 & 1 & 1 & 1 & 1 & 1 \\
\hline D8: Prospectus & 0.5 & 0.5 & 0.5 & 0.5 & 0.5 & 0.5 & 0.5 & 0.5 & 0.5 & 0.5 \\
\hline D9: Shareholders & 1 & 1 & 1 & 1 & 1 & 1 & 1 & 1 & 1 & 1 \\
\hline D10: Transactions & 0 & 0 & 0.5 & 0.5 & 0.5 & 0.5 & 0.5 & 0.5 & $1^{\mathrm{j}}$ & 1 \\
\hline \multirow[t]{2}{*}{ Disclosure Score } & 0.58 & 0.60 & 0.65 & 0.65 & 0.80 & 0.80 & 0.80 & 0.80 & 0.85 & 0.85 \\
\hline & 1991 & 1992 & 1993 & 1994 & 1995 & 1996 & 1997 & 1998 & 1999 & 2000 \\
\hline E1: Appointment & $1^{\mathrm{k}}$ & 1 & 1 & 1 & 1 & 1 & 1 & 1 & 1 & 1 \\
\hline E2: Auditor Independence & 0 & 0 & 0 & 0 & 0 & 0 & 0 & 0 & 0 & 0 \\
\hline E3: Focus & $1^{\mathrm{m}}$ & 1 & 1 & 1 & 1 & 1 & 1 & 1 & 1 & 1 \\
\hline E4: Rule-making Power & $0.5^{\mathrm{n}}$ & 0.5 & 0.5 & 0.5 & 0.5 & 0.5 & 0.5 & 0.5 & 0.5 & 0.5 \\
\hline E5: Tenure & $0^{\circ}$ & 0 & 0 & 0 & 0 & 0 & 0 & 0 & 0 & 0 \\
\hline E6: Document & $1^{\mathrm{p}}$ & 1 & 1 & 1 & 1 & 1 & 1 & 1 & 1 & 1 \\
\hline E7: Review & $1^{\mathrm{q}}$ & 1 & 1 & 1 & 1 & 1 & 1 & 1 & 1 & 1 \\
\hline E8: Sanctions Company & $1^{\mathrm{r}}$ & 1 & 1 & 1 & 1 & 1 & 1 & 1 & 1 & 1 \\
\hline E9: Sanctions Management & $0.5^{\mathrm{s}}$ & 0.5 & 0.5 & 0.5 & 0.5 & 0.5 & 0.5 & 0.5 & 0.5 & 0.5 \\
\hline E10: Sworn Statement & 0 & 0 & 0 & 0 & 0 & 0 & 0 & 0 & 0 & 0 \\
\hline Enforcement Score & 0.60 & 0.60 & 0.60 & 0.60 & 0.60 & 0.60 & 0.60 & 0.60 & 0.60 & 0.60 \\
\hline
\end{tabular}

Table A5, continued on next page 
Table B5, continued

\begin{tabular}{lrrrrrrrrrr}
\hline & 2001 & 2002 & 2003 & 2004 & 2005 & 2006 & 2007 & 2008 & 2009 & 2010 \\
\hline E1: Appointment & 1 & 1 & 1 & 1 & 1 & 1 & 1 & 1 & 1 & 1 \\
E2: Auditor Independence & 0 & 0 & 0.5 & 0.5 & 0.5 & 0.5 & 0.5 & 0.5 & $1^{1}$ & 1 \\
E3: Focus & 1 & 1 & 1 & 1 & 1 & 1 & 1 & 1 & 1 & 1 \\
E4: Rule-making Power & 0.5 & 0.5 & 0.5 & 0.5 & 0.5 & 0.5 & 0.5 & 0.5 & 0.5 & 0.5 \\
E5: Tenure & 0 & 0 & 0 & 0 & 0 & 0 & 0 & 0 & 0 & 0 \\
E6: Document & 1 & 1 & 1 & 1 & 1 & 1 & 1 & 1 & 1 & 1 \\
E7: Review & 1 & 1 & 1 & 1 & 1 & 1 & 1 & 1 & 1 & 1 \\
E8: Sanctions Company & 1 & 1 & 1 & 1 & 1 & 1 & 1 & 1 & 1 & 1 \\
E9: Sanctions Management & 0.5 & 0.5 & 0.5 & 0.5 & 0.5 & 0.5 & 0.5 & 0.5 & 0.5 & 0.5 \\
E10: Sworn Statement & 0 & 0 & $1^{\mathrm{t}}$ & 1 & 1 & 1 & 1 & 1 & 1 & 1 \\
\hline Enforcement Score & 0.60 & 0.60 & 0.75 & 0.75 & 0.75 & 0.75 & 0.75 & 0.75 & 0.80 & 0.80 \\
\hline
\end{tabular}

a Publicly listed companies were required to set up consolidated financial statements according to IFRS starting in fiscal year 2005. There was no option to apply IFRS before that year ((Jeanjean \& Stolowy 2008) p. 481)

b With the enactment of Act No. 83-353 of April 1983 and in accordance with Act No. 66-537 Art. 340, companies had to publish a management commentary (termed Rapport de Gestion). This provision was replaced by Art. L232-1 of the Commercial Code of France (CC-FR - Code de Commerce) in 2000. Starting from fiscal year 2002 and in line with its Art. L225-102-1, those companies have to widen their management commentary by information on environmental and social effects of their business activities as well as on the sustainability of potential social commitments (Act No. 2001-420 Art. 116). This additional information raises the score value to 0.5 .

c In line with Financial Markets Authority (AMF - Autorité des Marchés Financiers) General Regulation MF Art. 223-2, 221-4 and 621-1, listed companies in France are required to pursue the disclosure of material information. The latter was introduced in 1988 with Art. 30 of Act No. 88-04 so the score value is 1 over the entire observation period.

d Since 1985, companies listed on a regulated market have to publish half-yearly financial reports (Act No. 66-537 Art. 341-1; Decree No. 67-236 Art. 297-1). The regulation currently in force (Monetary and Financial Code (MFC - Code Monétaire et Financier) Art. L451-1-2) only requires the quarterly disclosure of selected financial items, but no condensed financial report.

e French GAAP required companies to disclose information on geographical or business segments from 1983 onwards (Decree 83-1020 Art. 24, No. 21). Also the provisions on segment reporting issued in 1999 (in the Plan Comptable Général, Regulation CRC No. 99-02 Art. 425) were less strict than e.g. the former IAS 14. The change to IFRS in 2005 rises the score value to 1.

f According to the Commercial Code (CC-FR Art. L225-102-1), companies in regulated markets are required to disclose the amount and the composition of each director's compensation payments. The requirement has been initiated by the Act No. 2001-420 of May 2001. Before its enactment, compensation payments had only be disclosed on an aggregated level for all board members ((Lele \& Siems 2007), p. 50).

$\mathrm{g}$ Companies have to reveal the direct and indirect ownership of its directors and board members, as well as of persons that are related to them (formerly settled in Act No. 66-537 Art. 162-1, now to be found in CC-FR Art. L225-109).

$\mathrm{h} \quad$ A requirement to issue a prospectus is enforced by the French Securities and Exchange Commission (COB - Commission des Opérations de Bourse) since its setup in 1967 ((Suckow 1975), p. 53), and this is still the duty of its successor, the AMF, which was created in 2003 (General Regulation of the AMF Art. 211-2). However, limitations to a general prospectus requirement for placements on regulated markets were found throughout the entire observation period, where small offerings were qualified as private or exempted from preparing a prospect (e.g. Regulation COB Art. 2\&3; MFC Art. L411-2). From 1987 onwards, companies were required to disclose an ownership stake if it exceeded $5 \%$ of the voting stock (Act No. 87-416; CC-FR Art. L233-7). 


\section{Table A5, concluded}

The obligation to report all securities transactions that involve the management or board members is settled in MFC Art. 621-18-2. It has been initiated by the Act No. 2003-706 of August 2003. The article did not require the disclosure of transactions that the management or board members carry out with shares of affiliated companies. This requirement has only been added in January 2009. We therefore start with a value of 0.5 in 2003 and change it into 1 in 2009.

k From 1989 onwards, the COB's and the AMF's chairmen have been appointed by decree of the president, the authority's members have been delegated by various public institutions, respectively (Act. No. 89-531Art. 2; MFC Art. L621-2). Thus, the variable takes the value 1 over the entire observation period.

1 The Commercial Code requires, as introduced in 2003 by Art. L822-11, an auditor to be independent. This provision was complemented by Art. L823-16 that explicitly requests a declaration of independence from auditors from 2008 onwards.

m From 1984 onwards the surveillance of commercial banks was carried out by the Banking Commission (Commission Bancaire). From 2010 onwards, this commissions was merged with others to form the Prudential Supervision Authority (Autorité de Contrôle Prudentiel). Stock exchanges have been supervised by the AMF and its predecessors ((Wymeersch 2007), p. 291).

n Since 1985, the COB was entitled to issue new regulations that needed to be authorized by the Ministry of Economy (Act No. 85-1321 Art. 31). This rule also applies to the AMF (MFC Art. L621-6; (Cervellati \& Fioriti 2007)).

o No explicit rules exist in the legal bases establishing the COB or the AMF regarding the tenure of its commission members. For that reason, we set the variable to 0 throughout the whole observation period.

p The COB was empowered since 1989, and the AMF has ever been empowered for investigation purposes to demand information from any person that has the ability to deliver information (Act No. 89-531 Art. 5ter; MFC Art. L621-12).

q The obligation to deliver periodic information existed prior to 1991 (Decree No. 67-236 Art. 296). Both the $\mathrm{COB}$ had and the AMF has the power to proactively review financial documents and demand the correction of accounts ((Lascoumes 1985), p. 8); (Hong Phu Dao 2005), p. 112).

$\mathrm{r} \quad$ The COB was and AMF is able to impose sanctions on misconducting companies. These sanctions include warnings, trade suspensions and financial penalties (Act No. 96-597 Art. 71; MFC Art. L62115). In case of criminal infringement and market manipulation, the AMF directs the reports to the public prosecutor. The predecessor of the AMF, the Conseil de Discipline de la Gestion Financière (CDF) was able to use the same sanctions ((Hong Phu Dao 2005), p. 112). Therefore we set the variable to 1 over the entire observation period.

s In line with Ordinance No. 67-833 Art. 10-1 the COB could and in line with MFC Art. L621-9 \& L62115 , the AMF can likewise sanction individuals that act on behalf of entities (see footnote $r$ ). There is no indication that those individuals can be sanctioned even when they are unaware of fraudulent actions. Management has to certify the correctness of financial reports in line with COB Regulation No. 200205 Art. 2 ter-1 (as endorsed by the Order of 18 June 2002). This requirement has been in place also under the AMF regime, currently set out in its General Rules Art. 212-14.

\section{Canada}

Capital market regulation in Canada is a special case since it is the only country within our sample with few institutions and rules at the national (i.e., federal) level. Each province or territory may issue own securities laws and empower own enforcement agencies, whereas banking supervision as well as accounting rules and practice have developed nationally (Zeff \& Radcliffe 2010). Most listed firms are traded at the Toronto Stock Exchange (TSX); hence for the past 30 years the Ontario Securities Act (SA-ON) is relevant where no federal regulation exists, and the Ontario Securities Commission (OSC) enforces this regulation. Generally, all aspects are more or less closely linked to U.S. provisions as a considerable share of TSX-listed firms is cross-listed on one of the New York exchanges, which ties them to U.S. rules (Zeff \& Radcliffe 2010). With respect to disclosure, both the Canadian and the U.S. regimes differed only in few items during our observation period. The relevant enforcement only caught up in 1994, and more prominently, in 2003/2004 when several regulations were introduced or amended that mirror the SOX (Carnaghan \& Gunz 2007). To this end, the Ontario administration strengthened the OSC (giving the power to impose administrative financial penalties, conducting a pro-active review of filing documents) and requires auditors to certify their independence. Other provincial regulations were superseded (e.g., remuneration disclosure, management commentary requirements) or accompanied by federal ones (directors' certification of financial reports) (Kuras 2004). In stylized terms, the Ontario/Canada case represents a "high regulation" regime. Table A6 describes disclosure and enforcement score values for Canada. 
Table A6: Score Values by Year, Ontario/Canada

This table shows the yearly disclosure and enforcement regulation score values and provide explanations for the changes in Canada for the period between 1991 and 2010.

\begin{tabular}{|c|c|c|c|c|c|c|c|c|c|c|}
\hline & 1991 & 1992 & 1993 & 1994 & 1995 & 1996 & 1997 & 1998 & 1999 & 2000 \\
\hline D1: Information Accounting & $1^{\mathrm{a}}$ & 1 & 1 & 1 & 1 & 1 & 1 & 1 & 1 & 1 \\
\hline D2: Mgmt. Commentary & 0.75 & 0.75 & 0.75 & 0.75 & 0.75 & 0.75 & 0.75 & 0.75 & 0.75 & 0.75 \\
\hline D3: Material Information & $1^{\mathrm{c}}$ & 1 & 1 & 1 & 1 & 1 & 1 & 1 & 1 & 1 \\
\hline D4: Quarterly Reports & $1^{\mathrm{d}}$ & 1 & 1 & 1 & 1 & 1 & 1 & 1 & 1 & 1 \\
\hline D5: Segment Information & 0.5 & 0.5 & 0.5 & 0.5 & 0.5 & 0.5 & 0.5 & $1^{\mathrm{e}}$ & 1 & 1 \\
\hline D6: Compensation & 0.5 & 0.5 & $1^{\mathrm{f}}$ & 1 & 1 & 1 & 1 & 1 & 1 & 1 \\
\hline D7: Inside Ownership & $1^{\mathrm{g}}$ & 1 & 1 & 1 & 1 & 1 & 1 & 1 & 1 & 1 \\
\hline D8: Prospectus & 0.5 & 0.5 & 0.5 & 0.5 & 0.5 & 0.5 & 0.5 & 0.5 & 0.5 & 0.5 \\
\hline D9: Shareholders & $1^{\mathrm{i}}$ & 1 & 1 & 1 & 1 & 1 & 1 & 1 & 1 & 1 \\
\hline D10: Transactions & $1^{\mathrm{j}}$ & 1 & 1 & 1 & 1 & 1 & 1 & 1 & 1 & 1 \\
\hline \multirow[t]{2}{*}{ Disclosure Score } & 0.83 & 0.83 & 0.88 & 0.88 & 0.88 & 0.88 & 0.88 & 0.93 & 0.93 & 0.93 \\
\hline & 2001 & 2002 & 2003 & 2004 & 2005 & 2006 & 2007 & 2008 & 2009 & 2010 \\
\hline D1: Information Accounting & 1 & 1 & 1 & 1 & 1 & 1 & 1 & 1 & 1 & 1 \\
\hline D2: Mgmt. Commentary & 0.75 & 0.75 & 0.75 & $1^{\mathrm{b}}$ & 1 & 1 & 1 & 1 & 1 & 1 \\
\hline D3: Material Information & 1 & 1 & 1 & 1 & 1 & 1 & 1 & 1 & 1 & 1 \\
\hline D4: Quarterly Reports & 1 & 1 & 1 & 1 & 1 & 1 & 1 & 1 & 1 & 1 \\
\hline D5: Segment Information & 1 & 1 & 1 & 1 & 1 & 1 & 1 & 1 & 1 & 1 \\
\hline D6: Compensation & 1 & 1 & 1 & 1 & 1 & 1 & 1 & 1 & 1 & 1 \\
\hline D7: Inside Ownership & 1 & 1 & 1 & 1 & 1 & 1 & 1 & 1 & 1 & 1 \\
\hline D8: Prospectus & 0.5 & 0.5 & 0.5 & 0.5 & 0.5 & 0.5 & 0.5 & 0.5 & 0.5 & $1^{\mathrm{h}}$ \\
\hline D9: Shareholders & 1 & 1 & 1 & 1 & 1 & 1 & 1 & 1 & 1 & 1 \\
\hline D10: Transactions & 1 & 1 & 1 & 1 & 1 & 1 & 1 & 1 & 1 & 1 \\
\hline \multirow[t]{2}{*}{ Disclosure Score } & 0.93 & 0.93 & 0.93 & 0.95 & 0.95 & 0.95 & 0.95 & 0.95 & 0.95 & 1.00 \\
\hline & 1991 & 1992 & 1993 & 1994 & 1995 & 1996 & 1997 & 1998 & 1999 & 2000 \\
\hline E1: Appointment & $0^{\mathrm{k}}$ & 0 & 0 & 0 & 0 & 0 & 0 & 0 & 0 & 0 \\
\hline E2: Auditor Independence & 0 & 0 & 0 & 0 & 0 & 0 & 0 & 0 & 0 & 0 \\
\hline E3: Focus & $1^{\mathrm{m}}$ & 1 & 1 & 1 & 1 & 1 & 1 & 1 & 1 & 1 \\
\hline E4: Rule-making Power & 0 & 0 & 0 & $0.5^{\mathrm{n}}$ & 0.5 & 0.5 & 0.5 & 0.5 & 0.5 & 0.5 \\
\hline E5: Tenure & $0^{\circ}$ & 0 & 0 & 0 & 0 & 0 & 0 & 0 & 0 & 0 \\
\hline E6: Document & $1^{\mathrm{p}}$ & 1 & 1 & 1 & 1 & 1 & 1 & 1 & 1 & 1 \\
\hline E7: Review & $0.5^{\mathrm{q}}$ & 0.5 & 0.5 & 0.5 & 0.5 & 0.5 & 0.5 & 0.5 & 0.5 & 0.5 \\
\hline E8: Sanctions Company & 0 & 0 & 0 & 0 & 0 & 0 & 0 & 0 & 0 & 0 \\
\hline E9: Sanctions Management & 0 & 0 & 0 & $0.5^{\mathrm{s}}$ & 0.5 & 0.5 & 0.5 & 0.5 & 0.5 & 0.5 \\
\hline E10: Sworn Statement & 0 & 0 & 0 & 0 & 0 & 0 & 0 & 0 & 0 & 0 \\
\hline Enforcement Score & 0.25 & 0.25 & 0.25 & 0.35 & 0.35 & 0.35 & 0.35 & 0.35 & 0.35 & 0.35 \\
\hline
\end{tabular}

Table A6, continued on next page 


\begin{tabular}{lrrrrrrrrrr} 
Table B6, continued & 2001 & 2002 & 2003 & 2004 & 2005 & 2006 & 2007 & 2008 & 2009 & 2010 \\
\hline E1: Appointment & 0 & 0 & 0 & 0 & 0 & 0 & 0 & 0 & 0 & 0 \\
E2: Auditor Independence & 0 & 0 & $1^{1}$ & 1 & 1 & 1 & 1 & 1 & 1 & 1 \\
E3: Focus & 1 & 1 & 1 & 1 & 1 & 1 & 1 & 1 & 1 & 1 \\
E4: Rule-making Power & 0.5 & 0.5 & 0.5 & 0.5 & 0.5 & 0.5 & 0.5 & 0.5 & 0.5 & 0.5 \\
E5: Tenure & 0 & 0 & 0 & 0 & 0 & 0 & 0 & 0 & 0 & 0 \\
E6: Document & 1 & 1 & 1 & 1 & 1 & 1 & 1 & 1 & 1 & 1 \\
E7: Review & 0.5 & 0.5 & $1^{\mathrm{q}}$ & 1 & 1 & 1 & 1 & 1 & 1 & 1 \\
E8: Sanctions Company & 0 & 0 & $1^{\mathrm{r}}$ & 1 & 1 & 1 & 1 & 1 & 1 & 1 \\
E9: Sanctions Management & 0.5 & 0.5 & 0.5 & 0.5 & 0.5 & 0.5 & 0.5 & 0.5 & 0.5 & 0.5 \\
E10: Sworn Statement & 0 & 0 & 0 & $1^{\mathrm{t}}$ & 1 & 1 & 1 & 1 & 1 & 1 \\
\hline Enforcement Score & 0.35 & 0.35 & 0.60 & 0.70 & 0.70 & 0.70 & 0.70 & 0.70 & 0.70 & 0.70 \\
\hline
\end{tabular}

a Canada: Canadian GAAP is usually regarded as similar to U.S. GAAP rules (e.g., (Meek 1983); (Bradshaw \& Miller 2008), p. 240). Since 2011, all listed firms are required to follow IFRS (National Instrument (NI) 52-107, 2011, s. 3.2 (1)(b)). Hence, item D1 is set to 1 throughout the entire sample period.

b Ontario: Until 1989, management commentary was a voluntary component of financial reports ((Zeff \& Radcliffe 2010), p. 105-106). In the following year, this disclosure became mandatory ((Clarkson et al. 1994), p. 424; Policy of the Ontario Securities Commission (OSC) 5.10). Canada: Since 2004, a national regulation exists which extended management commentary requirements to include e.g. statements on the effectiveness of internal control systems (Form 1 to NI 51-102).

c Ontario: Provisions of the Ontario Securities Act (SA-ON) require a news release on any material change (SA-ON, 1980, s. 74; current unchanged rule: SA-ON, 1994, s. 75).

d Ontario: Continuous quarterly financial reporting has been mandatory throughout the sample period (SA-ON, 1980, s. 76 (1)(b); current unchanged rule: SA-ON, 1990, s. 77 (1)(b)).

e Canada: Up to 1998, segment reporting followed the risks-and-return approach which allowed substantial discretion on what and how to report ((Roberts 2008), p. 435). Since 1999, the revised accounting rules in CICA Handbook Section 1700 are based on the management approach.

f Ontario: Between 1981 and 1992, listed firms were required to disclose the compensation paid to executives as a group ((Alboini 1980), p. 67; Form 30(6)). This was amended by 1993 when the individual remuneration to top executives had to be continuously reported ((Jordan 1995), s. 593; OSC Regulation 638/93). Canada: Since 2004, a federal regulation further extended these disclosure provisions (Form 6 to NI 51-102).

g Ontario: Ownership of any related party has to be continuously disclosed throughout the sample period (SA-ON, 1980, s. 102 (1); current unchanged rule: SA-ON, 1999, s. 107 (1)).

h Ontario: The exemption (SA-ON, 1980, s. $71(1)(d))$ that a prospectus is not compulsory for small placements was repealed in 2009. This is inconsistent with a general prospectus requirement for regulated markets, and we set $\mathrm{D} 8=0.5$ during this time span.

i Ontario: Since 1981 shareholdings owning $10 \%$ or more had to be reported ((Alboini 1980), p. 67; current unchanged rule: SA-ON, 2007, s. 102.1 (1)).

j Ontario: Directors' dealings have to be reported under the Securities Act SA-ON (1990) s. 109).

k Ontario: The members of the OSC are appointed by the Lieutenant Governor based on the decision of the Cabinet of Ontario (SA-ON, 1969, s. 2 (2); current unchanged rule: SA-ON, 1997, s. 3 (4)).

1 Ontario: Auditors have to state their independence since 2003 ((Kuras 2004), p. 473; (Green 2006), p. 40; SA-ON, 2003, s. 143 (1)25.iii).

$\mathrm{m}$ Canada: Supervision of banks has been carried out by separate federal institutions during the observation period. In 1987, the Office of the Inspector General of Banks was merged with the insurance supervision to create the Office of the Superintendent of Financial Institutions ((Goodhart \& Schoenmaker 1995), p. 559), the OSC is the securities and exchange commission in Ontario. There is no national commission in this area.

n Ontario: The OSC gained rule-making powers in 1994 (SA-ON, 1994, s. 143 (1)). However, any rule requires the approval of the Ontario Minister of Finance (SA-ON, 1994, s. 143.3 (3)). 
Ontario: No explicit rule exists in the Ontario Securities Act throughout the observation period. For that reason, (Taylor 1978)) finds that the tenure of commission members is unclear. Hence, we code $\mathrm{E} 5=0$.

p Ontario: As regulated by the Ontario Securities Act, the OSC can seize any relevant document (SAON, 1980, s. 11 (4); current unchanged rule: SA-ON, 1994, s. 13 (1)).

q Until 2003, the OSC filings were used to reactively enforce financial reports. From this year onwards, the continuous disclosure review was introduced which includes a pro-active enforcement of accounting rules (SA-ON, 2003, s. 20.1). This provision mirrors the SOX s. 408 in U.S. law.

$r$ Ontario: In 2003, the OSC was empowered to impose administrative fines. Since then both, financial and legal penalties can be issued against companies (SA-ON, 2003, s. 127 (1)).

s Ontario: Management can be sanctioned with fines or imprisonment if the person was aware of committing an offense (SA-ON, 1980, s. 118; current unchanged rule: SA-ON, 1994, s. 122). Until 1994, the Minister had to approve any sanction (SA-ON, 1994, s. 119 was repealed in this year); consequently, up to this year, item E9 is set to 0 .

$\mathrm{t}$ Canada: A certification of financial reports by directors is compulsory since 2004 ((Kuras 2004), p. 474; Form 1 to NI 52-109 - Part 3).

\section{References}

Aitken, M. J., Czernkowski, R. M. \& Hooper, C. G. (1994), "The Information Content of Segment Disclosures: Australian Evidence", Abacus 30, 65-77.

Akashi, T. (1989), "Regulation of Insider Trading in Japan", Columbia Law Review 89, 1296-1319.

Akerlof, G. A. (1970), "The Market for 'Lemons': Quality Uncertainty and the Market Mechanism", Quarterly Journal of Economics 84, 488-500.

Alboini, V. P. (1980), "The New Ontario Securities Act", Financial Analysts Journal 36, 64-69.

Aliev, R. A. \& Huseynov, O. H., (Yea)r. Decision Theory With Imperfect Information(World Scientific Publishing, Singapore).

Armstrong, C. S., Barth, M. E., Jagolinzer, A. D. \& Riedl, E. J. (2010), "Market Reaction to the Adoption of IFRS in Europe", The Accounting Review 85, 31-61.

Ashbaugh, H. \& Pincus, M. (2001), "Domestic Accounting Standards, International Accounting Standards, and the Predictability of Earnings", Journal of Accounting Research 39, 417-434.

Bae, K.-H., Tan, H. \& Welker, M. (2008), "International GAAP differences: The impact on foreign analysts", The Accounting Review 83, 593-628.

Bailey, W., Li, H., Mao, C. X. \& Zhong, R. (2003), "Regulation Fair Disclosure and Earnings Information: Market, Analyst, and Corporate Responses", The Journal of Finance 58, 2487-2514.

Ball, R., Kothari, S. P. \& Robin, A. (2000), "The effect of international institutional factors on properties of accounting earnings", Journal of Accounting and Economics 29, 1-51.

Barry, C. B. \& Brown, S. J. (1985), "Differential Information and Security Market Equilibrium", Journal of Financial \& Quantitative Analysis 20, 407-422.

Basu, S., Hwang, L. \& Jan, C.-L. (1998), "International Variation in Accounting Measurement Rules and Analysts' Earnings Forecast Errors", Journal of Business Finance \& Accounting 25, 1207-1247.

Bebenroth, R., Dietrich, D. \& Vollmer, U. (2009), "Bank regulation and supervision in bank-dominated financial systems: a comparison between Japan and Germany", European Journal of Law and Economics 27, 177-209.

Ben-Shahar, O. \& Schneider, C. E. (2014), "The Futility of Cost Benefit Analysis in Financial Disclosure Regulation", Working Paper, UM Law School.

Bhattacharya, U. \& Daouk, H. (2002), "The World Price of Insider Trading", The Journal of Finance 57, 75-108.

Botosan, C. A. (1997), "Disclosure level and the cost of equity capital", The Accounting Review 72, 323-349.

Bradshaw, M. T. \& Miller, G. S. (2008), "Will Harmonizing Accounting Standards Really Harmonize Accounting? Evidence from Non-U.S. Firms Adopting U.S. GAAP", Journal of Accounting, Auditing \& Finance 23, 233264.

Brochet, F., Jagolinzer, A. D. \& Riedl, E. J. (2013), "Mandatory IFRS Adoption and Financial Statement Comparability", Contemporary Accounting Research 30, 1373-1400.

Brown, P., Calderon, J. \& Lev, B. (2000), "Administrative and Judicial Approaches to Auditor Independence", Seton Hall Law Review 30, 443-463.

Brown, P., Preiato, J. P. \& Tarca, A. (2014), "Measuring Country Differences in Enforcement of Accounting Standards: An Audit and Enforcement Proxy", Journal of Business Finance \& Accounting 41, 1-52.

Brown, P. \& Tarca, A. (2005), "A commentary on issues relating to the enforcement of International Financial Reporting Standards in the EU", European Accounting Review 14, 181-212.

Brüggemann, U., Hitz, J.-M. \& Sellhorn, T. (2013), "Intended and Unintended Consequences of Mandatory IFRS 
Adoption: A Review of Extant Evidence and Suggestions for Future Research", European Accounting Review 22, 1-37.

Bushee, B. J. \& Leuz, C. (2005), "Economic consequences of SEC disclosure regulation: evidence from the OTC bulletin board", Journal of Accounting and Economics 39, 233-264.

Bushman, R. M., Piotroski, J. D. \& Smith, A. J. (2004), "What Determines Corporate Transparency?", Journal of Accounting Research 42, 207-252.

Byard, D., Li, Y. \& Yu, Y. (2011), "The Effect of Mandatory IFRS Adoption on Financial Analysts' Information Environment", Journal of Accounting Research 49, 69-96.

Carley, M. (2010), "Developments in industrial action 2005 - 2009", Working Paper, European Foundation of the Improvement of Living and Working Conditions.

Carnaghan, C. \& Gunz, S. P. (2007), "Recent Changes in the Regulation of Financial Markets and Reporting in Canada", Accounting Perspectives 6, 55-94.

Cervellati, E. M. \& Fioriti, E. (2007), "Financial Supervision in EU Countries", Working Paper, University of Bologna.

Christensen, H. B., Hail, L. \& Leuz, C. (2013), "Mandatory IFRS Reporting and Changes in Enforcement", Working Paper, Wharton School, Chicago Booth.

Clarkson, P. M., Kao, J. L. \& Richardson, G. D. (1994), "The Voluntary Inclusion of Forecasts in the MD\&A Section of Annual Reports", Contemporary Accounting Research 11, 423-450.

Cole, C. J. \& Jones, C. L. (2004), "The Usefulness of MD\&A Disclosures in the Retail Industry", Journal of Accounting, Auditing \& Finance 19, 361-388.

Coles, J. L., Loewenstein, U. \& Suay, J. (1995), "On Equilibrium Pricing under Parameter Uncertainty", The Journal of Financial and Quantitative Analysis 30, 347-364.

Cooke, T. E. \& Wallace, R. S. O. (1990), "Financial disclosure regulation and its environment: A review and further analysis", Journal of Accounting and Public Policy 9, 79-110.

Core, J. E., Hail, L. \& Verdi, R. (2015), "Mandatory Disclosure Quality, Inside Ownership, and Cost of Capital", European Accounting Review 24, 1-29.

Cunningham, L. A. (2002), "Semiotics, Hermeneutics, and Cash: An Essay on the True and Fair View", North Carolina Journal of International Law and Commercial Regulation 28, 893-934.

Daouk, H., Lee, C. M. C. \& Ng, D. (2006), "Capital market governance: How do security laws affect market performance?", Journal of Corporate Finance 12, 560-593.

Dasgupta, P. (2000), "Trust as a Commodity", in Gambetta, D. (ed.) Trust: Making and Breaking Cooperative Relations, electronic edition, University of Oxford, 49-72.

Daske, H., Hail, L., Leuz, C. \& Verdi, R. (2008), "Mandatory IFRS Reporting around the World: Early Evidence on the Economic Consequences", Journal of Accounting Research 46, 1085-1142.

Daske, H., Hail, L., Leuz, C. \& Verdi, R. (2013), "Adopting a Label: Heterogeneity in the Economic Consequences Around IAS/IFRS Adoptions", Journal of Accounting Research 51, 495-547.

Dhaliwal, D., Li, O. Z., Tsang, A. \& Yang, Y. G. (2014), "Corporate social responsibility disclosure and the cost of equity capital: The roles of stakeholder orientation and financial transparency", Journal of Accounting and Public Policy 33, 328-355.

Di Noia, C. \& Di Giorgio, G. (1999), "Should Banking Supervision and Monetary Policy Tasks Be Given to Different Agencies", International Finance 2, 361-378.

Easley, D. \& O'Hara, M. (2004), "Information and the Cost of Capital", The Journal of Finance 59, 1553-1583.

Eleswarapu, V. R., Thompson, R. \& Venkataraman, K. (2004), "The Impact of Regulation Fair Disclosure: Trading Costs and Information Asymmetry", Journal of Financial and Quantitative Analysis 39, 209-225.

Eleswarapu, V. R. \& Venkataraman, K. (2006), "The Impact of Legal and Political Institutions on Equity Trading Costs: A Cross-Country Analysis", Review of Financial Studies 19, 1081-1111.

Emmanuel, C. R. \& Garrod, N. (2002), "On the Relevance and Comparability of Segmental Data", Abacus 38, 215-234.

Engel, E., Hayes, R. M. \& Wang, X. (2007), "The Sarbanes-Oxley Act and firms' going-private decisions", Journal of Accounting and Economics 44, 116-145.

Ernstberger, J., Stich, M. \& Vogler, O. (2012), "Economic Consequences of Accounting Enforcement Reforms: The Case of Germany", European Accounting Review 21, 217-251.

Fearnley, S. \& Hines, T. (2003), "The regulatory framework for financial reporting and auditing in the United Kingdom: the present position and impending changes", The International Journal of Accounting 38, 215233.

Frank, M. Z. \& Goyal, V. K. (2003), "Testing the pecking order theory of capital structure", Journal of Financial Economics 67, 217-248.

Frino, A., Palumbo, R., Capalbo, F., Gerace, D. \& Mollica, V. (2013), "Information Disclosure and Stock Liquidity: Evidence from Borsa Italiana", Abacus 49, 423-440. 
Frost, C. A. \& Pownall, G. (1994), "Accounting Disclosure Practices in the United States and the United Kingdom", Journal of Accounting Research 32, 75-102.

Fu, R., Kraft, A. \& Zhang, H. (2012), "Financial reporting frequency, information asymmetry, and the cost of equity", Journal of Accounting and Economics 54, 132-149.

Giner, B. \& Rees, W. (2001), "On the Asymmetric Recognition of Good and Bad News in France, Germany and the United Kingdom", Journal of Business Finance \& Accounting 28, 1285-1331.

Goergen, M. \& Renneboog, L. (1998), "Strong Managers and Passive Institutional Investors in the UK: Stylized Facts", Working Paper, ECGI.

Goodhart, C. \& Schoenmaker, D. (1995), "Should the Functions of Monetary Policy and Banking Supervision Be Separated?", Oxford Economic Papers 47, 539-560.

Green, D. L. (2006), "Auditor Independence in Canada: A historical Perspective - From Shareholder Auditors to Modern-Day Audit Committees", Canadian Accounting Perspectives 5, 37-65.

Hablutzel, P. N. (1992), "British Bank's Role in U.K. Capital Markets since the Big Bang", Chicago Kent Law Review 68, 365-376.

Hail, L. \& Leuz, C. (2006), "International Differences in the Cost of Equity Capital: Do Legal Institutions and Securities Regulation Matter?", Journal of Accounting Research 44, 485-531.

Hassan, O. A., Romilly, P., Giorgioni, G. \& Power, D. (2009), "The value relevance of disclosure: Evidence from the emerging capital market of Egypt", The International Journal of Accounting 44, 79-102.

Healy, P. M. \& Palepu, K. G. (2001), "Information asymmetry, corporate disclosure, and the capital markets: A review of the empirical disclosure literature", Journal of Accounting and Economics 31, 405-440.

Heftel, C. L. (1983), "Corporate Governance in Japan: The Position of Shareholders in Publicly Held Corporations", University of Hawaii Law Review 5, 135-206.

High, D. \& Shah, N. (1993), "Financial Regulation Five Years on: The Investigative Powers of the SROs", Journal of Financial Regulation and Compliance 1, 347-354.

Hirose, A. (1991), "Recent Developments: Changes in Japanese Securities Law", Harvard International Law Journal 32, 508-516.

Hong Phu Dao, T. (2005), "Monitoring Compliance with IFRS: Some Insights from the French Regulatory System", Accounting in Europe 2, 107-135.

Hope, O.-K. (2003), "Disclosure Practices, Enforcement of Accounting Standards, and Analysts' Forecast Accuracy: An International Study", Journal of Accounting Research 41, 235-272.

Horton, J., Serafeim, G. \& Serafeim, I. (2013), "Does Mandatory IFRS Adoption Improve the Information Environment?", Contemporary Accounting Research 30, 388-423.

Hoshi, T. \& Ito, T. (2004), "Financial regulation in Japan: a sixth year review of the Financial Services Agency", Journal of Financial Stability 1, 229-243.

IMF (2003), "Japan: Financial System Stability Assessment and Supplementary Information", Washington D.C.

Itami, H. \& Itoh, K. (1982), "A Comparison of Corporate Financial Reporting in Japan and the United States", Working Paper, Standford University et al.

Iwasaki, T., Otomasa, S., Shiiba, A. \& Shuto, A. (2012), "Excess Executive Compensation and the demand for Accounting Conservatism", Working Paper, Kansai University et al.

Jeanjean, T. \& Stolowy, H. (2008), "Do accounting standards matter? An exploratory analysis of earnings management before and after IFRS adoption", Journal of Accounting and Public Policy 27, 480-494.

Jiao, T., Koning, M., Mertens, G. \& Roosenboom, P. (2012), "Mandatory IFRS adoption and its impact on analysts' forecasts", International Review of Financial Analysis 21, 56-63.

Jordan, C. (1995), "Regulation of Canadian Capital Markets in the 1990s: The United States in the Driver's Seat", Pacific Rim Law \& Policy Journal 4, 577-632.

Klein, R. W. \& Bawa, V. S. (1976), "The Effect of Estimation Risk on Optimal Portfolio Choice", Journal of Financial Economics 3, 215-231.

Kothari, S. P., Shu, S. \& Wysocki, P. D. (2009), "Do Managers Withhold Bad News?", Journal of Accounting Research 47, 241-276.

Krishnamurthy, S., Zhou, J. \& Zhou, N. (2006), "Auditor Reputation, Auditor Independence, and the Stock-Market Impact of Andersen's Indictment on Its Client Firms", Contemporary Accounting Research 23, 465-490.

Kubota, K., Suda, K. \& Takehara, H. (2010), "Impact of Quarterly Disclosure on Information Asymmetry: Evidence from Tokyo Stock Exchange Firms", Working Paper, Chuo University et al.

Kuras, R. O. (2004), "Harmonization of Securities Regulation Standards between Canada and the United States", University of Detroit Mercy Law Review 81, 465-476.

La Porta, R., Lopez-De-Silanes, F. \& Shleifer, A. (2006), "What Works in Securities Laws?", The Journal of Finance 61, 1-32.

La Porta, R., Lopez-De-Silanes, F., Shleifer, A. \& Vishny, R. W. (1997), "Legal Determinants of External Finance", The Journal of Finance 52, 1131-1150. 
Lambert, R., Leuz, C. \& Verrecchia, R. E. (2007), "Accounting Information, Disclosure, and the Cost of Capital", Journal of Accounting Research 45, 385-420.

Landsman, W. R. \& Maydew, E. L. (2002), "Has the Information Content of Quarterly Earnings Announcements Declined in the Past Three Decades?", Journal of Accounting Research 40, 797-808.

Lang, M. \& Lundholm, R. (1996), "Corporate Disclosure Policy and Analyst Behaviour", The Accounting Review 71, 467-492.

Lang, M. H., Lins, K. V. \& Miller, D. P. (2004), "Concentrated control, analyst following and valuation: Do analysts matter most when investors are protected least?", Journal of Accounting Research 42, 589-623.

Lascoumes, P. (1985), "La C.O.B.: entre magistrature économique et gestion du droit des affaires", Déviance et société 9, 1-30.

Lele, P. \& Siems, M. (2007), "Shareholder Protection: A Leximetric Approach", Journal of Corporate Law Studies 7, 17-50

Lerman, A. \& Livnat, J. (2010), "The new Form 8-K disclosures", Review of Accounting Studies 15, 752-778.

Leuz, C., Nanda, D. \& Wysocki, P. D. (2003), "Earnings management and investor protection: an international comparison", Journal of Financial Economics 69, 505-527.

Leuz, C. \& Verrecchia, R. E. (2000), "The Economic Consequences of Increased Disclosure", Journal of Accounting Research 38, 91-124.

Leuz, C. \& Wysocki, P. (2016), "The Economics of Disclosure and Financial Reporting Regulation: Evidence and Suggestions for Future Research", Journal of Accounting Research 54, 525-622.

Levine, R. \& Zervos, S. (1998), "Stock Markets, Banks, and Economic Growth", The American Economic Review 88, 537-558.

Lombardo, D. \& Pagano, M. (2002), "Law and Equity Markets: A Simple Model", Corporate Governance Regimes: Convergence and Diversity, 343-362.

Lorenz, M. (1987), "EEC Law and Other Problems in Applying the SEC Proposal on Multinational Offerings to the U.K.", The International Lawyer 21, 795-826.

Lu, S.-S. (1993), "Securities Regulation in Japan: An Update", Denver Journal of International Law \& Policy 22, $121-154$

Mackey, P. A., Stuber, W. D., Stuber, A. M., Kerbel, J., Kiyohara, K., Berg, K., Chanetsa, B., Hartmann, M., Gedik, H., Üçer, K. \& Bushner, D. (2005), "International Securities and Capital Markets", The International Lawyer 39, 373-402.

Markham, J. W. (2002), "Super Regulator: A Comparative Analysis of Securities and Derivatives Regulation in the United States, the United Kingdom, and Japan", Brookyn Journal of International Law 28, 319-410.

Meek, G. K. (1983), "U.S. Securities Market Responses to Alternate Earnings Disclosures of Non-U.S. Multinational Corporations", The Accounting Review 58, 394-402.

Meser, M., Veith, S. \& Zimmermann, J. (2015), "Disclosure, Enforcement and Capital Market Properties: A Longitudinal Analysis for Germany", Schmalenbach Business Review 67, 254-287.

Misawa, M. (1974), "Tokyo an an Iinternational Capital Market-Its Economic and Legak Aspects", Vanderbilt Journal of Transnational Law 8, 1-38.

Mizuno, M. (2010), "Institutional Investors, Corporate Governance and Firm Performance in Japan", Pacific Economic Review 15, 653-665.

Morris, M. S. (1993), "The Securities Enforcement Remedies and Penny Stock Reform Act of 1990: By Keeping up with the Joneses, the SEC's Enforcement Arsenal Is Modernized", Administrative Law Journal of the American University 7, 151-212.

Muntermann, J. \& Guettler, A. (2007), "Intraday stock price effects of ad hoc disclosures: the German case", Journal of International Financial Markets, Institutions and Money 17, 1-24.

Nobes, C. \& Parker, R. B., (Yea)r. Comparative International Accounting, 12. edition.(Prentice Hall, New Jersey).

Opong, K. K. (1995), "The Information Content of Interim Financial Reports: UK Evidence", Journal of Business Finance \& Accounting 22, 269-279.

Ozu, C. \& Gray, S. J. (2001), "The development of segment reporting in Japan: Achieving international harmonization through a process of national consensus", Advances in International Accounting 14, 1-13.

Pardieck, A. M. (2001), "The Formation and Transformation of Securities Law in Japan: From the Bubble to the Big Bang", UCLA Pacific Basin Law Journal 19, 1-91.

Paredes, T. A. (2003), "Blinded by the Light: Information Overload and its Consequences For Securities Regulation", Washington University Law Quarterly 81, 417-486.

Peters, A. L. (1988), "Independent Agencies: Government's Scourge or Salvation?", Duke Law Journal 1, 286296.

Pierce, M. A. (1981), "The Regulation of the Issuance and Trading of Securities in the United States and the European Economic Community: A Comparison", Journal of comparative corporate law and securities regulation 3, 129-150. 
Pimlott, G. F. (1985), "The Reform of Investor Protection in the U.K. - An Examination of the Proposals of the Gower Report and the U.K. Government's White Paper of January, 1985", Journal of Comparative Business and Capital Market Law 7, 141-172.

Ramsay, N. J. (1992), "Japanese Securities Regulation: Problems of Enforcement", Fordham Law Review 60, 255 284.

Ramseyer, J. M. (2011), "Insider Trading Regulation in Japan", Working Paper, Harvard Law School.

Richardson, A. J. \& Welker, M. (2001), "Social disclosure, financial disclosure and the cost of equity", Accounting, Organization \& Society 26, 597-616.

Roberts, C. B. (2008), "Segment reporting", Comparative International Accounting, 427-457.

Ruder, D., Sun, Y. \& Sycz, A. (2005), "The Securities and Exchange Commission's Pre- and Post-Enron Responses to Corporate Financial Fraud: An Analysis and Evaluation", Notre Dame Law Review 80, 1103-1158.

Schroeder, N. \& Gibson, C. (1990), "Readability of Management's Discussion and Analysis", Accounting Horizons 4, 78-87.

SESC (1994), "Outline of Activities July 1993 - June 1994", Tokyo.

SESC (2008), "Annual Report 2007/2008", Tokyo.

Sikka, P. \& Willmott, H. (1995), "Illuminating the State-Profession Relationship: Accountants acting as Department of trade and Industry Investigators", Critical Perspectives on Accounting 6, 341-369.

Small, R. (2003), "From Tatemae to Honne: A Historical Perspective on the Prohibition of Insider Trading in Japan", Washington University Global Studies Law Review 2, 313-352.

Strohmenger, M. (2014), "Enforcement Releases, Firm Characteristics, and Earnings Quality: Insights from Germany's Two-tiered Enforcement System", Journal of International Financial Management \& Accounting 25, 271-304.

Suckow, S. (1975), "The European Prospectus", American Journal of Comparative Law 23, 50-68.

Tan, H., Wang, S. \& Welker, M. (2011), "Analyst Following and Forecast Accuracy After Mandated IFRS Adoptions", Journal of Accounting Research 49, 1307-1357.

Tatsuta, M. (1978), "Enforcement of Japanese Securities Legislation", Journal of Comparative Corporate Law and Securities Regulation 1, 95-138.

Taylor, G. E. (1978), "Comments on the Mandate and Operation of the Ontario Securities Commission", University of Toronto Faculty of Law Review 36, 1-43.

Terrion, H. F. (1993), "Regulation S-K, Item 402: The New Executive Compensation Disclosure Rules", Case Western Reserve Law Review 43, 1175-1197.

Verrecchia, R. E. (2001), "Essays on disclosure", Journal of Accounting and Economics 32, 97-180.

White, B. J. (2015), "How do Investors React to Fair Value Estimates that Reveal Bad News? The Role of Investment Horizon", Working Paper.

Wiseman, J. (1982), "An evaluation of environmental disclosures made in corporate annual reports", Accounting, Organizations \& Society 7, 53-63.

Wisenbaker, C. T. (2010), "Japan's Financial Instruments and Exchange Law: Hercules or Hydra?", Georgia Journal of International and Comparative Law 38, 473-510.

Wymeersch, E. (2007), "The Structure of Financial Supervision in Europe: About Single Financial Supervisors, Twin Peaks and Multiple Financial Supervisors", European Business Organization Law Review 8, 237-306.

Zeff, S. A. \& Radcliffe, V. S. (2010), "The Ontario Securities Commission on Accounting and Auditing from the 1960s to 2008 - Part 1: 1960s to 1985", Accounting Perspectives 9, 29-53.

Zeff, S. A. \& Radcliffe, V. S. (2010), "The Ontario Securities Commission on Accounting and Auditing from the 1960s to 2008 - Part 2: The First Four Chief Accountants, 1986 - 1996", Accounting Perspectives 9, 97-138. 